\title{
Proceedings from the 2018 Canadian Association for the Study of the Liver Single Topic Conference-Decompensated cirrhosis: from clinic to transplant
}

\author{
Victor Dong $\mathrm{MD}^{1^{*}}$, Maxime Gosselin MD,BSc, FRCPC $2^{*}$, Nishita Jagarlamudi MBBS, MPH, FRACP ${ }^{*}$, \\ Beverley Kok MD ${ }^{*}$, Mark G Swain MD, MSc, FRCPC5 , Jasmohan S Bajaj MD ${ }^{6}$, Juan $G$ \\ Abraldes $\mathrm{MD}^{7}$, Vladimir Marquez MDCM, MSc, FRCPC ${ }^{8}$, R Todd Stravitz MD, FAASLD', \\ Aldo J Montano-Loza MD, MSc, PhD, FAASLD4, Manuela Merli MD ${ }^{10}$, Phil Wong MD, MSc ${ }^{11}$, \\ Amanda Brisebois $M D^{12}$, Puneeta Tandon $M D^{4}$, Julia Wendon $M B C h B, M R C P, F R C P C^{13}$, \\ Scott L Nyberg MD, PhD ${ }^{14}$, François M Carrier MD ${ }^{15}$, Michael R Lucey MD ${ }^{16}$, \\ Florence Wong $\mathrm{MD}^{3}$, Jordan J Feld MD ${ }^{17}$, Constantine J Karvellas MD, SM, FRCPC ${ }^{18 \dagger}$, \\ Christopher F Rose PhD ${ }^{19 \dagger}$, Julien Bissonnette MD' ${ }^{20 \dagger}$
}

KEYWORDS: acute-on-chronic liver failure, decompensated cirrhosis, liver transplantation

Author Affiliation

${ }^{1}$ Division of Gastroenterology, University of Alberta, Edmonton, Alberta; ${ }^{2}$ Hôpital de Verdun, Montréal, Québec; ${ }^{3}$ Division of Gastroenterology, Toronto General Hospital, University of Toronto, Toronto, Ontario; ${ }^{4}$ Division of Gastroenterology and Liver Unit, University of Alberta, Edmonton, Alberta; ${ }^{5}$ Division of Gastroenterology and Hepatology, University of Calgary, Calgary, Alberta; ${ }^{\circ}$ Division of Gastroenterology, Hepatology and Nutrition, Virginia Commonwealth University and McGuire VA Medical Center, Richmond, Virginia, USA; ${ }^{7}$ Cirrhosis Care Clinic, Division of Gastroenterology (Liver Unit), University of Alberta, Edmonton; ${ }^{8}$ Division of Gastroenterology, Vancouver General Hospital, Vancouver; ${ }^{9}$ Hume-Lee Transplant Center, Virginia Commonwealth University, Richmond, Virginia; ${ }^{10}$ Gastroenterology and Hepatology Unit, Sapienza University of Rome, Rome, Italy; ${ }^{11}$ Division of Gastroenterology and Hepatology, McGill University, Montréal, Québec; ${ }^{12}$ Division of General Internal Medicine, Department of Medicine and Division of Palliative Care, Department of Oncology, University of Alberta, Edmonton, Alberta; ${ }^{13}$ Institute of Liver Studies, King's College Hospital, London, United Kingdom; ${ }^{14}$ Division of Transplantation Surgery, Mayo Clinic, Rochester, MN; ${ }^{15}$ Centre de Recherche du Centre Hospitalier de l'Université de Montréal (CRCHUM), Montréal, Québec; ${ }^{16}$ Division of Gastroenterology and Hepatology, University of Wisconsin School of Medicine and Public Health, Madison, WI; ${ }^{17}$ Toronto Centre for Liver Disease, Toronto General Hospital, Toronto, Ontario; ${ }^{18}$ Department of Critical Care Medicine and Division of Gastroenterology, University of Alberta, Edmonton, Alberta; ${ }^{19}$ Hepato-Neuro Laboratory, CRCHUM, Université de Montréal, Montréal, Québec; ${ }^{20}$ Service d'hépatologie, Centre Hospitalier de l'Université de Montréal, Montréal, Québec

Correspondence: Julien Bissonnette, 803-264, boulevard René-Lévesque est, Montréal, Quebec H2X 1P1. E-mail: julien.bissonnette@Umontreal.ca

* Joint first authors

${ }^{\dagger}$ Joint senior authors 
SESSION 1-HEPATIC ENCEPHALOPATHY

\section{CONFERENCE 1: GUT-LIVER-BRAIN AXIS IN CIRRHOSIS-C ROSE}

Hepatic encephalopathy (HE) is a debilitating complication of cirrhosis characterized by cognitive, psychiatric, and motor disturbances. The deterioration of brain function due to liver disease manifests as a wide spectrum of neurological abnormalities ranging from subclinical alterations to coma. Its diagnosis requires exclusion of other known brain diseases. Onset of HE is associated with a higher mortality than other causes of decompensation of cirrhosis (1).

Ammonia is the main and most studied pathophysiologic factor in HE. Ammonia levels are increased in cirrhosis due to spontaneous porto-systemic shunting and hepatocellular dysfunction. Ammonia, having chemical properties similar to potassium, readily crosses the blood-brain barrier and cellular membranes and is transformed to glutamine in astrocytes, causing swelling and cerebral edema (2) and leading to dysfunction of the astrocyte-neuron unit and yielding variable levels of cerebral dysfunction. Elevated blood ammonia levels are associated with a worse prognosis in cirrhotic patients (3). Its toxicity on other organs, including skeletal muscle, has also been shown to have deleterious effects $(4,5)$.

Other key actors in the pathogenesis of HE include systemic inflammation and oxidative stress. Many studies have highlighted their role as aggravating factors to the neuropsychological effects of hyperammonemia (6-8). Another factor that has recently generated interest is elevated lactate levels at the cerebral level (9).

$\mathrm{HE}$ is part of a continuum including covert $\mathrm{HE}$, diagnosed only using psychometric tests, and overt HE. It is known that patients with covert HE are at a higher risk of presenting with overt $\mathrm{HE}$ and that a first episode of overt $\mathrm{HE}$ is associated with a more that $50 \%$ risk of recurrent $\mathrm{HE}$ at 6 months $(10,11)$. $\mathrm{HE}$, a metabolic disorder, is assumed to completely resolve following liver transplantation. However, several studies have reported persisting neurological complications in $15 \%-45 \%$ of transplanted patients $(12,13)$. It is now thought that recurrent HE leads to irreversible brain injury via senescence and neuronal cell loss before surgery $(14,15)$. Moreover, liver transplantation is a major procedure associated with blood loss, hypotension, complex anaesthesia and immunosuppressive medication that have worse impacts on a brain frailed by previous exposition to HE.

Because of its significant burden on the quality of life and functioning of patients and their caregivers, better identification of patients at risk of HE remains an unmet clinical need in patients with cirrhosis to implement better preventive strategies.

\section{REFERENCES}

1. Jepsen P, Ott P, Andersen PK, Sørensen HT, Vilstrup H. Clinical course of alcoholic liver cirrhosis: a Danish population-based cohort study. Hepatology. 2010;51(5):1675-82. https:/ / doi.org/10.1002/hep.23500.Medline: 20186844

2. BosoiCR, RoseCF. Identifying the directeffects of ammonia on the brain. Metab Brain Dis. 2009;24(1):95-102. https://doi.org/10.1007/ s11011-008-9112-7. Medline:19104924

3. Patwardhan VR, Jiang ZG, Risech-Neiman Y, Piatkowski G, Afdhal NH, Mukamal K, et al. Serum Ammonia in Associated With Transplant-free Survival in Hospitalized Patients With Acutely Decompensated Cirrhosis. J Clin Gastroenterol. 2016;50(4): 345-50. https://doi.org/10.1097/MCG. 0000000000000443. Medline:26565968

4. Dasarathy S, Mookerjee RP, Rackayova V, Rangroo Thrane V, Vairappan B, Ott $\mathrm{P}$, et al. Ammonia toxicity: from head to toe? Metab Brain Dis. 2017;32(2):529-38. https:/ / doi.org/10.1007/s11011-016-9938-3. Medline:28012068

5. Davuluri G, Krokowski D, Guan B-J, Kumar A, Thapaliya S, Singh D, et al. Metabolic adaptation of skeletal muscle to hyperammonemia drives the beneficial effects of L-leucine in cirrhosis. J Hepatol. 2016, 65(5):929-37; https://doi.org/10.1016/j.jhep. 2016.06.004. Medline:27318325

6. Shawcross DL, Davies NA, Williams R, Jalan R. Systemic inflammatory response exacerbates the neuropsychological effects of induced hyperammonemia in cirrhosis. J Hepatol. 2004;40(2):247-54. https://doi.org/10.1016/ j.jhep.2003.10.016. Medline:14739095 
7. Görg B, Qvartskhava N, Bidmon H-J, Palomero-Gallagher N, Kircheis G, Zilles $\mathrm{K}$, et al. Oxidative stress markers in the brain of patients with cirrhosis and hepatic encephalopathy. Hepatology. 2010;52(1):256265. https://doi.org/10.1002/hep.23656. Medline:20583283

8. Montoliu C, Cauli O, Urios A, ElMlili N, Serra MA, Giner-Duran R, et al. 3-NitroTyrosine as a Peripheral Biomarker of Minimal Hepatic Encephalopathy in Patients With Liver Cirrhosis. Am J Gastroenterol. 2011;106(9):1629-37. https://doi. org/10.1038/ajg.2011.123. Medline:21483460

9. Bosoi CR, Zwingmann $\mathrm{C}$, Marin $\mathrm{H}$, ParentRobitaille C, Huynh J, Tremblay M, et al. Increased brain lactate is central to the development of brain edema in rats with chronic liver disease. J Hepatol. 2014;60(3):554-60. https://doi.org/10.1016/j.jhep.2013.10.011. Medline:24512824

10. Patidar KR, Thacker LR, Wade JB, Sterling RK, Sanyal AJ, Siddiqui MS, et al. Covert hepatic encephalopathy is independently associated with poor survival and increased risk of hospitalization. Am J Gastroenterol. 2014;109(11):1757-63. https://doi. org/10.1038/ajg.2014.264. Medline:25178701

11. Sharma BC, Sharma P, Agrawal A, Sarin SK. Secondary prophylaxis of hepatic encephalopathy: an open-label randomized controlled trial of lactulose versus placebo. Gastroenterology. 2009;137(3):885-91， 891. e1. https://doi.org/10.1053/j.gastro.2009. 05.056. Medline:19501587

12. Campagna F, Montagnese S, Schiff S, Biancardi A, Mapelli D, Angeli P, et al. Cognitive impairment and electroencephalographic alterations before and after liver transplantation: What is reversible? Liver Transpl. 2014;20(8):977-86. https://doi. org/10.1002/lt.23909. Medline:24809329

13. Atluri DK, Asgeri $M$, Mullen KD. Reversibility of hepatic encephalopathy after liver transplantation. Metab Brain Dis. 2010;25(1):111-3. https://doi.org/10.1007/ s11011-010-9178-x. Medline:20204484

14. Görg B,KarababaA,ShafigullinaA,BidmonHJ, Häussinger D. Ammonia-induced senescence in cultured rat astrocytes and in human cerebral cortex in hepatic encephalopathy. Glia. 2015;63(1):37-50. https://doi.org/10.1002/ glia.22731. Medline:25092802

15. García-Lezana T, Oria M, Romero-Giménez J, Bové J, Vila M, Genescà J, et al. Cerebellar neurodegeneration in a new rat model of episodic hepatic encephalopathy. J Cereb Blood Flow Metab. 2017;37(3):927-37. https:/ / doi.org/10.1177/0271678X16649196. Medline:27154504

\section{CONFERENCE 2: PRE-CIRRHOTIC COGNITIVE DECLINE-M SWAIN}

Many cognitive domains can be potentially impacted by liver disease including attention, processing speed, executive functions, reaction time, working memory, and visual-spatial function. Dysfunction in one or more of these domains is often referred to by patients as "brain fog".

Hepatic encephalopathy is the most known and studied neurological complication of liver disease. It is classically associated with cirrhosis. However, cerebral dysfunction occurring at earlier stages of fibrosis is generally under-studied.

Primary biliary cholangitis (PBC) has been used as a model to study pre-cirrhotic cerebral dysfunction as its diagnosis is based on robust criteria and as patients present a high burden of symptoms including pruritus, fatigue, depression, but also cognitive dysfunction.

Magnetic resonance imaging (MRI) studies have revealed multiple alterations in the central nervous system of patients with pre-cirrhotic PBC compared with healthy controls, including:

- Decreased amplitude of low-frequency fluctuations (ALFF), a sign of spontaneous neural activity of the insula, a region where interoceptive signals are integrated with emotional, cognitive, and motivational signals.

- Decrease in the size of the hippocampus, a key structure for emotional and cognitive processes, a change similar to that in patients with neurological disorders such as multiple sclerosis and Alzheimer's disease.

- Increased hippocampal susceptibility assessed by quantitative susceptibility mapping, an indicator of local neuroinflammation $(1,2)$. 
- Alteration in the resting state functional connectivity of neural networks of the deep gray matter in patients with non-cirrhotic PBC compared with healthy controls and in nonresponders to ursodeoxycholic acid compared with responders (3).

- Various signalling pathways have been proposed to explain CNS dysfunction in patients with non-cirrhotic disease (4):

- Humoral route through pro-inflammatory cytokines

- Immune route through immune cell activation

- Systemic inflammation originating in the gut through dysbiosis and altered permeability leading to increased cytokines, pathogen-associated molecular patterns (PAMPs) (5)

Better understanding of the CNS dysfunction occurring in pre-cirrhotic patients has the potential to improve quality of life and prevent overt hepatic encephalopathy.

\section{REFERENCES}

1. van Bergen JMG, Li X, Hua J, Schreiner SJ, Steininger SC, Quevenco FC, et al. Colocalization of cerebral iron with Amyloid beta in Mild Cognitive Impairment. Sci Rep. 2016;6:35514. https: / / doi.org/10.1038/srep35514. Medline:27748454

2. MosherVAL,SwainMG,PangJXQ,KaplanGG, Sharkey KA, MacQueen GM, et al. Magnetic resonance imaging evidence of hippocampal structural changes in patients with primary biliary cholangitis. Clin Transl Gastroenterol. 2018;9(7):169. https://doi.org/10.1038/ s41424-018-0038-z. Medline:29977030

3. Mosher VAL, Swain MG, Pang JXQ, et al (2017) Primary Biliary Cholangitis Alters Functional Connections of the Brain's Deep Gray Matter. Clin Transl Gastroenterol 8:e107. https://doi.org/10.1038/ctg.2017.34

4. Swain MG, Jones DEJ. Fatigue in chronic liver disease: New insights and therapeutic approaches. Liver International. 2018;39(1): 6-19. https://doi.org/10.1111/liv.13919. Medline: 29935104

5. Azhari H, Swain MG. Role of Peripheral Inflammation in Hepatic Encephalopathy. J Clin Exp Hepatol. 2018;8(3):281-5. https:// doi.org/10.1016/j.jceh.2018.06.008. Medline: 30302045

\section{CONFERENCE 3: DIAGNOSIS AND MANAGEMENT OF HEPATIC ENCEPHALOPATHY-JS BAJAJ}

Hepatic encephalopathy (HE) is brain dysfunction caused by liver dysfunction and / or porto-systemic shunting (Table 1). It manifests as a wide spectrum of neurologic and psychiatric abnormalities from subtle alterations in psychometric tests to hepatic coma (1). HE is an important cause of morbidity in cirrhosis, being responsible for many hospital readmissions and an important detrimental effect on the quality of life of patients and caregivers.

Covert HE is present in $40 \%-60 \%$ of patients with cirrhosis. It can only be diagnosed using specialized testing. It is associated with a higher risk of progression to overt HE, worse socio-economic status, poorer quality of life, falls and poor driving skills, death, and hospitalizations (2-4). In the real-world setting, diagnostic tests include the EncephalApp, the SIP questionnaire or the Animal naming test (5-7). Current evidenced-based therapeutic strategies include lactulose, rifaximin, and probiotics (8-10).

The management of an acute episode of overt HE implies confirmation of the diagnosis, protection of the airway, and identification of the precipitating factor. Common precipitating factors include infections, gastrointestinal bleeding, electrolyte abnormalities, and dehydration. Clues against the diagnosis of HE include new focal deficits, excitatory motor activity and intoxication with alcohol or sedative drugs. Blood ammonia levels are not useful in an individual patient as they do not add diagnostic or staging information, unless they are normal, in which case HE is practically excluded. Polyethylene glycol (PEG) has a therapeutic interest in patients with high-grade HE (11). At the time of discharge, evaluation of the autonomy of the patient and caregiver education are essential and the question of liver transplantation must be brought up.

The first-line treatment to prevent HE recurrence is lactulose (12). Its use implies patient education on dose adjustment, adverse effect management and counselling of family members. The second-line treatment in patients with recurrent HE despite lactulose or who are lactulose-intolerant is rifaximin (13). Non-pharmacologic options include nutritional therapy with optimal energy intake, no dietary protein restriction, and frequent meals, including a late-night snack; stress reduction therapy; and physical therapy (14-15). 
Table 1: Classification of HE

\begin{tabular}{|c|c|c|c|c|}
\hline Type & Grade & & Time course & Presence of precipitating factor \\
\hline A (acute liver failure) & Covert & Minimal & Episodic & Precipitated \\
\hline B (porto-systemic bypass) & & 1 & Recurrent & \\
\hline \multirow[t]{3}{*}{ C (cirrhosis) } & Overt & 2 & & Spontaneous \\
\hline & & 3 & Persistent & \\
\hline & & 4 & & \\
\hline
\end{tabular}

Management of refractory cases includes ruling out alternate diagnoses, incorrect diagnosis and treatment of precipitating factors; consideration of spontaneous porto-systemic shunt embolization; liver transplantation; and participation in research protocols for new options such as fecal microbiota transplantation (16-19).

\section{REFERENCES}

1. Vilstrup H,AmodioP, BajajJ,Cordoba J,Ferenci $\mathrm{P}$, Mullen KD, et al. Hepatic encephalopathy in chronic liver disease: 2014 Practice Guideline by the American Association for the Study Of Liver Diseases and the European Association for the Study of the Liver. Hepatology. 2014;60(2):715-35. https://doi.org/10.1002/ hep.27210. Medline:25042402

2. Ampuero J, Simón M, Montoliú C, Jover R, Serra MÁ, Córdoba J, et al. Minimal Hepatic Encephalopathy and Critical Flicker Frequency Are Associated With Survival of Patients With Cirrhosis. Gastroenterology. 2015;149(6):1483-9. https://doi.org/10.1053/j.gastro.2015.07. 067. Medline:26299413

3. Kappus MR, Bajaj JS. Covert hepatic encephalopathy: not as minimal as you might think. Clin Gastroenterol Hepatol. 2012;10(11):1208-19. https://doi.org/ 10.1016/j.cgh.2012.05.026. Medline:22728384

4. Patidar KR, Thacker LR, Wade JB, Sterling RK, Sanyal AJ, Siddiqui MS, et al. Covert hepatic encephalopathy is independently associated with poor survival and increased risk of hospitalization. Am J Gastroenterol. 2014;109(11):1757-63. https://doi.org/ 10.1038/ajg.2014.264. Medline:25178701
5. Nabi E, Thacker LR, Wade JB, Sterling RK, Stravitz RT, Fuchs M, et al. Diagnosis of covert hepatic encephalopathy without $\mathrm{s}$ pecialized tests. Clin Gastroenterol Hepatol. 2014;12(8):1384-89.e2. https://doi.org/10. 1016/j.cgh.2013.12.020. Medline:24362049

6. Allampati S, Duarte-Rojo A, Thacker LR, Patidar KR, White MB, Klair JS, et al. Diagnosis of Minimal Hepatic Encephalopathy Using Stroop EncephalApp: A Multicenter US-Based, Norm-Based Study. Am J Gastroenterol. 2016;111(1):78-86. https:/ / doi. org/10.1038/ajg.2015.377. Medline:26644276

7. Campagna F, Montagnese S, Ridola L, Senzolo M, Schiff S, Rui MD, et al. The animal naming test: An easy tool for the assessment of hepatic encephalopathy. Hepatology. 2017;66(1):198 208. https://doi.org/10.1002/hep.29146. Medline:28271528

8. Prasad S, Dhiman RK, Duseja A, Chawla YK, Sharma A, Agarwal R. Lactulose improves cognitive functions and health-related quality of life in patients with cirrhosis who have minimal hepatic encephalopathy. Hepatology. 2007;45(3):549-59. https://doi. org/10.1002/hep.21533. Medline:17326150

9. Sidhu SS, Goyal O, Parker RA, Kishore H, Sood A. Rifaximin vs. lactulose in treatment of minimal hepatic encephalopathy. Liver Int. 2016;36(3):378-85. https://doi.org/10.1111/ liv.12921. Medline:26201713

10. Bajaj JS, Saeian K, Christensen KM, Hafeezullah M, Varma RR, Franco J, et al. Probiotic Yogurt for the Treatment of Minimal Hepatic Encephalopathy. Am J Gastroenterol. 2008;103(7):1707-15.https:/ /doi.org/10.1111/ j.1572-0241.2008.01861.x. Medline:18691193 
11. Rahimi RS, CuthbertJA, Rockey DC. Lactulose vs Polyethylene Glycol for Treatment of Hepatic Encephalopathy-Reply. JAMA Intern Med. 2015;175(5):868-9. https://doi.org/ 10.1001/jamainternmed.2015.0334. Medline: 25938322

12. Sharma P, Sharma BC (2015) Management of overt hepatic encephalopathy. J Clin Exp Hepatol 5:S82-87. https://doi.org/10.1016/ j.jceh.2014.04.004

13. Bass NM, Mullen KD, Sanyal A, Poordad F, Neff G, Leevy CB, et al. Rifaximin treatment in hepatic encephalopathy. $\mathrm{N}$ Engl J Med. 2010;362(12):1071-81. https:// doi.org/10.1056/NEJMoa0907893. Medline: 20335583

14. Duarte-Rojo A, Ruiz-Margáin A, MontañoLoza AJ, Macías-Rodríguez RU, Ferrando A, Kim WR. Exercise and physical activity for patients with end-stage liver disease: Improving functional status and sarcopenia while on the transplant waiting list. Liver Transpl. 2018;24(1):122-39. https://doi. org/10.1002/lt.24958. Medline:29024353

15. Amodio P, Bemeur C, Butterworth R, Cordoba J, Kato A, Montagnese S, et al. The nutritional management of hepatic encephalopathy in patients with cirrhosis: International society for hepatic encephalopathy and nitrogen metabolism consensus. Hepatology. 2013;58(1):325 -336. https:/ / doi.org/10.1002/ hep.26370. Medline:23471642

\section{SESSION 2-BLEEDING AND} COAGULOPATHY IN CIRRHOSIS

\section{CONFERENCE 4: PRIMARY VARICEAL SCREENING: IS ENDOSCOPY REQUIRED?-JG ABRALDES}

It is known that the identification and prophylactic treatment of high-risk varices can significantly reduce the 1-year risk of variceal bleeding. Therefore, endoscopic screening for esophageal varices has become part of the standard of care of the cirrhotic patient. The prevalence of high-risk varices is estimated to be $10 \%$ to $15 \%$ in compensated cirrhosis (1) and given the earlier diagnosis of compensated cirrhosis with transient elastography scan, these numbers might even be lower. This means that $80 \%$ to $95 \%$ of screening endoscopies in compensated cirrhosis do not result in a therapeutic action. Studies have looked at non-invasive tools (NIT) to identify patients at very low risk of having moderate or large-sized varices in which prophylaxis of bleeding is indicated and in whom diagnostic endoscopy could be avoided.

The ANTICIPATE trial brought data to develop a model for the identification of patients with varices needing treatment (VNT) (2). In this population of 518 patients with Child A compensated cirrhosis in five centres, non-invasive tests including liver stiffness measurement and spleen size assessment were performed, paired with upper gastrointestinal endoscopy and hepatic venous pressure gradient measurement (HVPG) in some. The combination of liver stiffness, spleen size, and platelet count performed best at assessing the presence of VNT. In this cohort, in which the criteria proposed in the Baveno VI consensus to avoid upper endoscopy, platelet count over $150 \times 10^{9} / \mathrm{L}$ and liver elastography below $20 \mathrm{kPa}$, the predicted risk of VNT was at $5 \%$. In a subsequent study including new cohorts with lower risk of VNT (5\%), platelet count above $110 \times 10^{9} / \mathrm{L}$, and transient elastography measurement below $25 \mathrm{kPa}$ could spare $32 \%$ endoscopies with even fewer $(1.9 \%)$ missed VNT (3). This led to the proposed Expanded Baveno VI criteria that might work well in settings with very low risk of VNT.

However, in patients with non-alcoholic fatty liver disease related cirrhosis, those with a bodymass index (BMI) below 30 and using M Probe, it appears that the Baveno VI criteria should be preferred since the expanded criteria led to an excess of 7\% missed VNT (4). This same observation has been made in cholestatic liver disease population (PBC and PSC) with excess of missed VNT using expanded Baveno VI criteria (5).

For the prevention of cirrhosis decompensation, the use of a non-selective beta-blocker (NSBB) was ineffective to prevent varices and variceal bleeding in patients with portal hypertension (HVPG of $6 \mathrm{mmHg}$ or more) and no varices at baseline (6). The PREDESCI study randomized 201 patients with compensated cirrhosis and clinically significant portal hypertension (HVPG at or above $10 \mathrm{mmHg}$ ) with small or no varices to receive propranolol or 
placebo for those with acute propranolol response or carvedilol or placebo for non-responders. The primary endpoint was new cirrhosis decompensation with a median follow-up of 3 years. Liver cirrhosis etiology was mostly alcohol and hepatitis $C$ and both groups had an average MELD score of 7 . The mean HVPG was also similar at $15 \mathrm{mmHg}$. The use of NSBB allowed to decrease by half the incidence of cirrhosis decompensation at 48 months. This result was mainly driven by decreased occurrence of ascites, but this strategy did not prevent development of high-risk varices and reduce bleeding rates, probably because band ligation was performed in those showing high-risk varices (7). Therefore, beta-blockers should be considered in those with compensated disease and clinically significant portal hypertension to prevent decompensation.

\section{REFERENCES}

1. North Italian Endoscopic Club for the Study and Treatment of Esophageal Varices. Prediction of the first variceal hemorrhage in patients with cirrhosis of the liver and esophageal varices. A prospective multicenter study. N Engl J Med. 1988; 319(15):983-9. https://doi.org/10.1056/ NEJM198810133191505. Medline:3262200

2. AbraldesJG,BureauC, StefanescuH,Augustin $S$, Ney $M$, Blasco $H$, et al. Noninvasive tools and risk of clinically significant portal hypertension and varices in compensated cirrhosis: The "Anticipate" study. Hepatology. 2016;64(6):2173-84. https:/ / doi.org/10.1002/ hep.28824. Medline:27639071

3. Augustin S, Pons M, Maurice JB, Bureau C, Stefanescu H, Ney M, et al. Expanding the Baveno VI criteria for the screening of varices in patients with compensated advanced chronic liver disease. Hepatology. 2017;66(6):1980-8. https://doi.org/10.1002/ hep.29363. Medline:28696510

4. Petta S, Sebastiani G, Bugianesi E, Viganò M, Wong VW-S, Berzigotti A, et al. Non-invasive prediction of esophageal varices by stiffness and platelet in non-alcoholic fatty liver disease cirrhosis. J Hepatol. 2018;69(4):878-85. https://doi.org/10.1016/j.jhep.2018.05.019. Medline:29802949

5. Moctezuma-Velazquez C, Saffioti F, TasaycoHuamanS, CasuS, Mason A, Roccarina D, et al.
Non-Invasive Prediction of High-Risk Varices in Patients with Primary Biliary Cholangitis and Primary Sclerosing Cholangitis. Am J Gastroenterol. 2019;114(3):446-52. https:// doi.org/10.1038/s41395-018-0265-7. Medline:30315285

6. Groszmann RJ, Garcia-Tsao G, Bosch J, Grace ND, Burroughs AK, Planas R, et al. Beta-Blockers to Prevent Gastroesophageal Varices in Patients with Cirrhosis. $N$ Engl J Med. 2005;353(21):2254-61. https:/ / doi.org/10.1056/nejmoa044456. Medline:16306522

7. Villanueva C, Albillos A, Genescà J, GarciaPaganJC,CallejaJL,AracilC, etal.Betablockers to prevent decompensation of cirrhosis in patients with clinically significant portal hypertension (PREDESCI): a randomised, double-blind, placebo-controlled, multicentre trial. The Lancet [Internet]. 2019;393(10181): 1597-1608; Available from: https://doi. org/10.1016/s0140-6736(18)31875-0

\section{CONFERENCE 5: VARICEAL BLEEDING: HOW CAN WE IMPROVE THE OUTCOME?-J BISSONNETTE}

During upper gastrointestinal bleeding, a restrictive hemoglobin $(\mathrm{Hb})$ target transfusion strategy of $\mathrm{Hb}>70 \mathrm{~g} / \mathrm{L}$ has been shown to significantly decrease 45 day mortality when compared with a liberal target $\mathrm{Hb}>90 \mathrm{~g} / \mathrm{L}$, including Child-Pugh A and $B$ patients (1).

The early (within 2 hours) use of hemostatic powder, in adjunction to usual pharmacotherapy, with repeated definitive therapeutic endoscopy within 12 to 24 hours led to high short-term endoscopic hemostasis, as well as an absolute decrease of $23 \%$ of 6-week mortality compared with standard pharmacologic and endoscopic management during acute variceal bleeding (AVB) in a randomized trial (2). This option can be considered in acute variceal bleeding for less experienced endoscopists and for massive bleeding situations. It also highlights the importance of early endoscopic treatment.

Self-expanding esophageal stents (SX-ELLA Stent Danis ${ }^{\circledR}$ ) have become an interesting alternative to balloon tamponade for refractory AVB. In a small randomized controlled trial, its use 
significantly decreased the occurrence of deleterious adverse events and improved hemostasis at 15 days compared with balloon tamponade. Although not demonstrated in small trials with cirrhotic patients, a survival benefit was observed in the acute-on-chronic liver failure setting as a bridge to transplantation in patients with refractory bleeding and contra-indication to transjugular intrahepatic portosystemic shunt (TIPS) $(3,4)$.

TIPS is commonly indicated in AVB with failure of endoscopic treatment and for early rebleeding. In an unselected cirrhotic population who underwent successful early endoscopic hemostasis, TIPS was superior to prevent recurrence of bleeding at 36 months but did not improve survival and was associated with higher rates of early hepatic encephalopathy when compared with standard management with endoscopic band ligation and non-selective beta-blockers (5). Patients with a hepatic venous pressure gradient (HVPG) during the index AVB over $20 \mathrm{mmHg}$ seem to have a survival benefit from TIPS (6). This led to the landmark trial of early TIPS strategy (7) where a hemostatic and survival benefit were observed in Child-Pugh $B$ patients with active bleeding at endoscopy and Child-Pugh C with 10 to 13 points in which TIPS was performed. These results were confirmed in an observational non-randomized study when applying the same inclusion and exclusion criteria (8). In another observational study, this survival benefit was found in the Child-Pugh C population, but not in Child-Pugh B patients with active bleeding (9). Two randomized controlled trials are underway in Scotland and China to confirm these results in Child $>7$ population. In a French multicentre audit, there was no trend in survival benefit using the early TIPS strategy in 326 patients eligible over a population of 964 patients with portal hypertension-related bleeding. Early TIPS was performed in only $7 \%$ of eligible cases, primarily because of no local availability or lack of belief in beneficial effect. This raises the question of applicability of such recommendations to real-life practice (10).

General anaesthesia may underestimate the real HPVG. In an observational study, the effect of deep sedation showed more than $10 \%$ difference with the awake HPVG (11). After TIPS insertion, fewer bleeding and ascites were noticed if the HPVG was below $12 \mathrm{mmHg}$ on short-term follow-up (12). Hence, TIPS revision can be used prior to discharge.

For post discharge management, simvastatin in conjunction with standard medical treatment improved survival without reducing rebleeding rates in a randomized controlled trial studying its use in secondary prevention (13). In animal models, this observation is thought to be the effect of decreased portal pressure by decreasing portal resistance. The precise role of statins in patients with cirrhosis needs further studies. A meta-analysis has highlighted the importance of NSBB in improving 24-month survival in Child-Pugh B/C populations in adjunction to EVL after variceal bleeding. However, this improvement in survival has not been demonstrated in Child-Pugh A patients (14).

There are two endovascular treatments for gastric variceal bleeding. Namely, balloon-occluded retrograde transvenous obliteration (BRTO) and TIPS can be considered in this setting. There are no comparative studies, but both have hemostatic success above $90 \%$. There are lower rates of ascites and rebleeding with a combined technique. Because of the opposing effects on the portal hemodynamics, several factors should be taken in consideration: presence of ascites, encephalopathy, vascular anatomy, contra-indication to TIPS, and local experience (15-17).

\section{REFERENCES}

1. Villanueva $\mathrm{C}$, Colomo $\mathrm{A}$, Bosch $\mathrm{A}$, Concepción M, Hernandez-Gea V, Aracil C, et al. Transfusion strategies for acute upper gastrointestinal bleeding. $\mathrm{N}$ Engl J Med. 2013;368(1):11-21. https://doi.org/10.1056/ NEJMoa1211801. Medline:23281973

2. Ibrahim M, El-Mikkawy A, Hamid MA, Abdalla H, Lemmers A, Mostafa I, et al. Early application of haemostatic powder added to standard management for oesophagogastric variceal bleeding: a randomised trial. Gut. 2018;68(5):844-53. https://doi.org/10.1136/ gutjnl-2017-314653. Medline:29730601

3. Escorsell À, Pavel O, Cárdenas A, Morillas R, Llop E, Villanueva C, et al. Esophageal balloon tamponade versus esophageal stent in controlling acute refractory variceal bleeding: A multicenter randomized, controlled trial. Hepatology. 2016;63(6):1957-67. https:/ / doi. org/10.1002/hep.28360. Medline:26600191

4. Maiwall R, Jamwal KD, Bhardwaj A, Bhadoria AS, Maras JS, Kumar G, et al. SX-Ella Stent Danis Effectively Controls Refractory Variceal Bleed in Patients with Acute-on-Chronic 
Liver Failure. Dig Dis Sci. 2017;63(2):493-501. https:/ /doi.org/10.1007/s10620-017-4686-8. Medline:28780608

5. Holster IL, Tjwa ETTL, Moelker A, Wils A, Hansen BE, Vermeijden JR, et al. Covered transjugular intrahepatic portosystemic shunt versus endoscopic therapy $+\beta$-blocker for prevention of variceal rebleeding. Hepatology. 2016;63(2):581-9. https://doi. org/10.1002/hep.28318. Medline:26517576

6. Monescillo A, Martínez-Lagares F, Ruiz-DelArbol L, Sierra A, Guevara C, Jiménez E, et al. Influence of portal hypertension and its early decompression by TIPS placement on the outcome of variceal bleeding. Hepatology. 2004;40(4):793-801. https:/ / doi.org/10.1002/ hep.1840400408. Medline:15382120

7. García-Pagán JC, Caca K, Bureau C, Laleman W, Appenrodt B, Luca A, et al. Early Use of TIPS in Patients with Cirrhosis and Variceal Bleeding. N Engl J Med. 2010;362(25):2370-9. https://doi.org/10.1056/nejmoa0910102. Medline:20573925

8. Garcia-Pagán JC, Di Pascoli M, Caca K, Laleman W, Bureau C, Appenrodt B, et al. Use of early-TIPS for high-risk variceal bleeding: results of a post-RCT surveillance study. J Hepatol. 2013;58(1):45-50. https:// doi.org/10.1016/j.jhep.2012.08.020. Medline:22940408

9. Hernández-Gea V, Procopet B, Giráldez Á, Amitrano L, Villanueva C, Thabut D, et al. Preemptive-TIPS Improves Outcome in HighRisk Variceal Bleeding: An Observational Study. Hepatology. 2019;69(1):282-93. https:/ / doi.org/10.1002/hep.30182. Medline:30014519

10. Thabut D, Pauwels A, Carbonell N, Remy AJ, Nahon P,CausseX, etal.Cirrhotic patients with portal hypertension-related bleeding and an indication for early-TIPS: a large multicentre audit with real-life results. J Hepatol. 2017;68(1):73-81. https://doi.org/10.1016/j. jhep.2017.09.002. Medline:28918131

11. Reverter E, Blasi A, Abraldes JG, MartínezPalli G, Seijo S, Turon F, et al. Impact of deep sedation on the accuracy of hepatic and portal venous pressure measurements in patients with cirrhosis. Liver Int. 2013;34(1):16-25. https:/ / doi.org/10.1111/liv.12229. Medline:23763484
12. Silva-Junior G, Baiges A, Turon F, Torres F, Hernández-Gea V, Bosch J, et al. The prognostic value of hepatic venous pressure gradient in patients with cirrhosis is highly dependent on the accuracy of the technique. Hepatology. 2015;62(5):15841592. https://doi.org/10.1002/hep.28031. Medline:26238376

13. Abraldes JG, Villanueva $C$, Aracil $C$, Turnes $\mathrm{J}$, Hernandez-Guerra M, Genesca J, et al. Addition of Simvastatin to Standard Therapy for the Prevention of Variceal Rebleeding Does Not Reduce Rebleeding but Increases Survival in Patients With Cirrhosis. Gastroenterology. 2016;150(5):11601170.e3. https://doi.org/10.1053/j. gastro.2016.01.004. Medline:26774179

14. Albillos A, Zamora J, Martínez J, Arroyo D, Ahmad I, De-la-Peña J, et al. Stratifying risk in the prevention of recurrent variceal hemorrhage: Results of an individual patient meta-analysis. Hepatology. 2017;66(4):1219_ 1231. https://doi.org/10.1002/hep.29267. Medline:28543862

15. Chen H-J, Jiao $Y$, Zhu X-Q, Zhang H-Y, Liu J-C, Wen $S$, et al. Brain Dysfunction Primarily Related to Previous Overt Hepatic Encephalopathy Compared with Minimal Hepatic Encephalopathy: Resting-State Functional MR Imaging Demonstration. Radiology. 2013;266(1):26170. https://doi.org/10.1148/radiol.12120026. Medline:23047839

16. Saad WE, Wagner C, Lippert A, AlOsaimi A, Davies MG, Matsumoto AH, et al. Protective Value of TIPS Against the Development of Hydrothorax/Ascites and Upper Gastrointestinal Bleeding after Balloon-Occluded Retrograde Transvenous Obliteration (BRTO). Am J Gastroenterol. 2013;108(10):1612-9. https://doi. org/10.1038/ajg.2013.232. Medline:23939627

17. Gaba RC, Omene BO, Podczerwinski ES, Knuttinen MG, Cotler SJ, Kallwitz ER, et al. TIPS for treatment of variceal hemorrhage: clinical outcomes in 128 patients at a single institution over a 12-year period. J Vasc Interv Radiol. 2012;23(2):227-35. https://doi.org/10.1016/j.jvir.2011.10.015. Medline:22178037 
CONFERENCE 6: PORTAL VEIN

\section{THROMBOSIS: WHEN TO}

\section{ANTICOAGULATE?-V MARQUEZ}

Because of the lack of clinical evidence and the heterogeneity of studies and populations, there are only few guidelines with limited strength of recommendations for the management of portal vein thrombosis (PVT).

In the non-cirrhotic population, unprovoked PVT can be associated with malignancy, myeloproliferative disorders, and inherited or acquired thrombophilia. These conditions should be investigated and adequately treated. Anticoagulation should be initiated and seems beneficial to prevent extension into mesenteric veins and bowel ischemia. Duration of treatment is usually 3 to 6 months but should be prolonged when an underlying prothrombotic condition persists or when the patient has presented with superior mesenteric vein involvement. Recanalization usually occurs before 6 months. Portal biliopathy, caused by compression of the biliary tree when the portal vein thrombosis becomes chronic, occurs in $30 \%$ of patients after 12 months.

The prevalence, natural history and management of PVT is different in cirrhotic patients. In a European registry of Child A and B cirrhotic patients, the cumulative incidence was $10.7 \%$ at 5 years, with a spontaneous recanalization of a non-occlusive thrombi of $70 \%$. PVT was not independently associated with liver disease progression or decompensation (1). This is different for Child C patients, where there was a survival advantage in patients who achieved recanalization with anticoagulation (2). In liver transplant candidates, anticoagulation is generally indicated after prophylaxis of variceal bleeding to maximize the chances of portal vein patency at the time of transplantation. PVT at the time of transplant was associated with increased mortality and graft failure at 90 days (3) but using this same database, other authors found no difference in outcome if the PVT was present at the time of listing (4). The explanation for this difference might reside in the extension of the PVT, since complete PVT was an independent risk factor for mortality as opposed to neutral effect of partial PVT in a retrospective cohort study (5).

The bleeding risk in patients with cirrhosis receiving anticoagulation is increased compared with patients receiving anticoagulation for venous thromboembolism, but not when compared with matched cirrhotic patients not receiving anticoagulation. Therefore, the increase in the bleeding risk seems related to portal hypertension rather than anticoagulation itself (6). The platelet count threshold of $50 \times 10^{9} / \mathrm{L}$ has been identified as a cut-off below which the bleeding risk significantly increases with anticoagulation (7).

Predictors of spontaneous recanalization have not been identified in high-quality studies. Case reports have described that the factors that predict recanalization are provoked events, non-occlusive thrombi, and early recanalization (8-10). In cohort studies, there was no association found with age, thrombus localization, MELD score, Child category, decompensation, ascites, variceal bleeding or kidney function $(11,12)$. Also, in another cohort study, the mean size of largest collateral, by diverting flow from the main portal vein, and portal vein flow were negatively associated with spontaneous recanalization (13).

For those undergoing anticoagulation, predictors of successful therapy include: recent time of onset, early initiation and degree of thrombus burden (14). The recurrence after discontinuing the anticoagulation ranges between $27 \%$ and $38 \%$ (15).

Small studies have suggested effectiveness and safety of direct-acting oral anticoagulants in patients with Child-Pugh A cirrhosis (16-18).

In conclusion, the decision to treat PVT in cirrhosis should be individualized and based on multiple factors: acuteness, symptomatology, extension and thrombus burden, bleeding risk, and liver transplantation candidacy. In contrario, patients with fully collateralized chronic PVT (carvernoma) are unlikely to benefit from anticoagulation. All these factors have to be balanced in terms of risks and benefits. Life expectancy should be taken into account, particularly in Child B-C patients who are not transplant candidates. Randomized controlled trials are needed and outcomes should include potential risks of treatment versus no treatment. The duration of anticoagulation should be at least 6 months with imaging follow-up to assess recanalization.

\section{REFERENCES}

1. Nery F, Chevret S, Condat B, de Raucourt E, Boudaoud L, Rautou P-E, et al. Causes and consequences of portal vein thrombosis 
in 1,243 patients with cirrhosis: results of a longitudinal study. Hepatology. 2015;61(2):660-7. https://doi.org/10.1002/ hep.27546. Medline:25284616

2. Senzolo M, Riva N, Dentali F, RodriguezCastro K, Sartori MT, Bang S-M, et al. LongTerm Outcome of Splanchnic Vein Thrombosis in Cirrhosis. Clin Transl Gastroenterol. 2018;9(8):176. https:/ / doi.org/10.1038/s41424018-0043-2. Medline:30108204

3. Ghabril M, Agarwal S, Lacerda M, Chalasani N, Kwo P, Tector AJ. Portal Vein Thrombosis Is a Risk Factor for Poor Early Outcomes After Liver Transplantation. Transplantation. 2016;100(1):126-133. https:/ / doi.org/10.1097/tp.0000000000000785. Medline:26050013

4. Berry K, Taylor J, Liou IW, Ioannou GN. Portal vein thrombosis is not associated with increased mortality among patients with cirrhosis. Clin Gastroenterol Hepatol. 2015;13(3):585-93. https://doi.org/10.1016/j. cgh.2014.10.010. Medline:25459555

5. Karvellas CJ, Cardoso FS, Senzolo M, Wells M, Alghanem MG, Handou F, et al. Clinical Impact of Portal Vein Thrombosis Prior to Liver Transplantation: A Retrospective Cohort Study. Ann Hepatol. 2017;16(2):236-436. https://doi.org/10.5604/16652681.1231582

6. La Mura V, Braham S, Tosetti G, Branchi F, Bitto N, Moia M, et al. Harmful and Beneficial Effects of Anticoagulants in Patients With Cirrhosis and Portal Vein Thrombosis. Clin Gastroenterol Hepatol. 2018;16(7):1146-1152. e4. https://doi.org/10.1016/j.cgh.2017.10. 016. Medline:29066371

7. Delgado MG, Seijo S, Yepes I, Achécar L, Catalina MV, García-Criado A, et al. Efficacy and safety of anticoagulation on patients with cirrhosis and portal vein thrombosis. Clin Gastroenterol Hepatol. 2012;10(7):776-83. https://doi.org/10.1016/j.cgh.2012.01.012. Medline:22289875

8. Spahr L, Willems B, Gianfelice D, PomierLayrargues G, Fenyves D. Spontaneously reversibleextensiveportalvein thrombosisafter gallbladder puncture during transjugular liver biopsy. J Hepatol. 1996;24(2):246-248. https: / / doi.org/10.1016/s0168-8278(96)80037-7
9. Borja A, Xing W, Lymen E, Azucena B, Sule AA. ThrombusResolutioninTwoPatientswithPortal Vein Thrombosis without Anticoagulation: Do We Need to Anticoagulate Patients with Portal Vein Thrombosis? Int J Angiol. 2016;25(5):e936. https://doi.org/10.1055/s-0034-1395980. Medline:28031666

10. Lai YC, Yang SS, Wu CH. Portal vein thrombosis after splenectomy in a patient with liver cirrhosis and esophageal varices. J Med Ultrasound. 1997;(5):21-5.

11. Luca A, Caruso S, Milazzo M, Marrone G, Mamone G, Crinò $F$, et al. Natural Course of Extrahepatic Nonmalignant Partial Portal Vein Thrombosis in Patients with Cirrhosis. Radiology. 2012;265(1):124-132. https: / / doi.org/10.1148/radiol.12112236. Medline:22891357

12. Chen H, Liu L, Qi X, He C, Wu F, Fan D, et al. Efficacy and safety of anticoagulation in more advanced portal vein thrombosis in patients with liver cirrhosis. Eur J Gastroenterol Hepatol. 2016;28(1):82-9. https://doi.org/ 10.1097/MEG.0000000000000482. Medline: 26513611

13. Maruyama $\mathrm{H}$, Okugawa $\mathrm{H}$, Takahashi M, Yokosuka O. De novo Portal Vein Thrombosis in Virus-Related Cirrhosis: Predictive Factors and Long-Term Outcomes. Am J Gastroenterol. 2013;108(4):568-74. https: / / doi.org/10.1038/ajg.2012.452. Medline:23381015

14. Intagliata NM, Argo CK, Stine JG, Lisman T, Caldwell SH, Violi F, et al. Concepts and Controversies in Haemostasis and Thrombosis Associated with Liver Disease: Proceedings of the 7 th International Coagulation in Liver Disease Conference. Thromb Haemost. 2018;118(8):1491-506. https: / / doi.org/10.1055/s-0038-1666861. Medline:30060258

15. Senzolo M, Sartori TM, Rossetto V, Burra $\mathrm{P}$, Cillo U, Boccagni $\mathrm{P}$, et al. Prospective evaluation of anticoagulation and transjugular intrahepatic portosistemic shunt for the management of portal vein thrombosis in cirrhosis. Liver Int. 2012;32(6):919-927. https: / / doi.org/10.1111/j.1478-3231.2012. 02785.x. Medline:22435854 
16. De Gottardi A, Trebicka J, Klinger C, Plessier A, Seijo S, Terziroli B, et al. Antithrombotic treatment with direct-acting oral anticoagulants in patients with splanchnic vein thrombosis and cirrhosis. Liver Int. 2017;37(5):694-9. https://doi.org/10.1111/ liv.13285. Medline:27778440

17. Steffel J, Verhamme $P$, Potpara TS, Albaladejo P, Antz M, Desteghe L, et al. The 2018 European Heart Rhythm Association Practical Guide on the use of nonvitamin $\mathrm{K}$ antagonist oral anticoagulants in patients with atrial fibrillation. Eur Heart J. 2018;39(16):1330-93. https:// doi.org/10.1093/eurheartj / ehy136. Medline:29562325

18. Priyanka P, Kupec JT, Krafft M, Shah NA, Reynolds GJ. Newer Oral Anticoagulants in the Treatment of Acute Portal Vein Thrombosis in Patients with and without Cirrhosis. Int J Hepatol. 2018;2018:8432781. https:/ / doi.org/10.1155/2018/8432781. Medline:29973997

\section{CONFERENCE 7: COAGULOPATHY IN CIRRHOSIS-RT STRAVITZ}

The bleeding tendency in patients with liver disease differs based on the clinical condition, as shown in Table 1. Patients with stable cirrhosis have mild synthetic failure as demonstrated by small increases of the International Normalised Ratio (INR), with moderate thrombocytopenia secondary to the moderate portal hypertension and minimal systemic inflammation. Acute liver failure presents with minimal or no portal hypertension and variable levels of systemic inflammation, but dramatically increased INR due to impaired synthetic function. In acute-on-chronic liver failure (ACLF), portal hypertension, failure of liver synthetic function is severe, worse failure and thrombocytopenia and important systemic inflammation.

As reported by Tripodi et al (1), conventional coagulation tests such as prothrombin time and activated partial thromboplastin time are inadequate to estimate the global coagulation function of a cirrhotic patient. This is based on the following observations:
Table 1. Coagulopathy patterns in different settings of liver failure

\begin{tabular}{llll} 
Feature & $\begin{array}{l}\text { Stable } \\
\text { Cirrhosis }\end{array}$ & $\begin{array}{l}\text { Acute } \\
\text { Liver } \\
\text { Failure }\end{array}$ & $\begin{array}{l}\text { Unstable } \\
\text { Cirrhosis } \\
\text { (ACLF) }\end{array}$ \\
\hline $\begin{array}{llll}\text { Portal Hypertension } \\
\text { Synthetic Failure } / \uparrow\end{array}$ & ++ & $-l+$ & +++ \\
$\quad$ INR & + & +++ & +++ \\
$\begin{array}{l}\text { Thrombocytopenia } \\
\text { Systemic } \\
\text { Inflammation }\end{array}$ & ++ & + & +++ \\
\hline
\end{tabular}

- Patients with cirrhosis rarely bleed apart from complications of portal hypertension.

- When they do bleed, the sites and types of bleeding are different than patients with hereditary or acquired factor deficiencies.

- Patients with cirrhosis have an increase tendency to develop thrombosis.

Although it is a powerful prognostic tool in acute or chronic liver disease, the INR does not predict acute variceal bleeding and its correction with recombinant factor VIIa does not improve patient outcomes in this setting (2). Also, it does not predict bleeding complications after invasive procedures in patients with cirrhosis. However, a platelet count below $60 \times 10^{9} / \mathrm{L}$ is associated with a higher risk of bleeding complications after liver biopsy (3). This threshold is correlated in vitro with preserved thrombin generation if the platelet count is above $60 \times 10^{9} / \mathrm{L}(4)$.

In fact, several studies support the fact that stable cirrhotic patients are in a more hypercoagulable state: increased risk of portal vein thrombosis, increased risk of venous thromboembolism in hospitalized patients, and increased risk for ischemic stroke when adjusted for risks factors. Levels of von Willebrand factor, and factor VIII increase with progression of the liver disease, at least partly due to bacterial translocation and gut-derived endotoxin $(5,6)$. This leads to an increased factor VIII/protein $C$ ratio (7), which tips the balance between procoagulant and anticoagulant factors towards a slightly hypercoagulable state despite decreased thrombocytopenia and decreased coagulation factors.

The same observation has been made in patients with acute liver failure where bleeding 
complications occur at a relatively low incidence despite profound derangements in hemostasis tests. The global hemostasis is rebalanced or tipped slightly toward hypercoagulability, as shown by thromboelastography (8) and thrombin generation (9) studies. There is also a compensation for thrombocytopenia with increased vWF levels which lead to increased platelet adherence.

In an ACLF cohort, the predictors of major bleeding events were bleeding on admission, fibrinogen under $60 \mathrm{mg} / \mathrm{dL}$, thrombocytopenia under $30 \times 10^{9} / \mathrm{L}$, and aPTT higher than $100 \mathrm{sec}(10)$. This hypocoagulability is also found in vitro as demonstrated by thromboelastrometry of a series of patients with ACLF (11).

With regards to blood products use in patients with cirrhosis, there are no studies that support the administration of fresh frozen plasma to correct INR. However, the target of platelets should be above 50 to $60 \times 10^{9} / \mathrm{L}$, fibrinogen above $100 \mathrm{mg} / \mathrm{dL}$ and hemoglobin level above $7 \mathrm{~g} / \mathrm{dL}$. These recommendations apply for pre-procedure prophylaxis in stable cirrhosis but are even more important in unstable cirrhotic patients with active bleeding (12).

Therefore, it has been demonstrated that patients with different stages of liver disease in the acute condition have complex coagulopathy concurrent defects in pro-hemostatic and anti-hemostatic pathways that may lead to both thrombosis and bleeding.

\section{REFERENCES}

1. Tripodi A, Salerno F, Chantarangkul V, Clerici M, Cazzaniga M, Primignani $M$, et al. Evidence of normal thrombin generation in cirrhosis despite abnormal conventional coagulation tests. Hepatology. 2005;41(3):55358. https://doi.org/10.1002/hep.20569. Medline:15726661

2. Bendtsen F, D'Amico G, Rusch E, de Franchis $R$, Andersen PK, Lebrec D, et al. Effect of recombinant Factor VIIa on outcome of acute variceal bleeding: an individual patient based meta-analysis of two controlled trials. J Hepatol. 2014;61(2):252-9. https://doi.org/10.1016/j. jhep.2014.03.035. Medline:24713188

3. Seeff LB, Everson GT, Morgan TR, Curto TM, Lee WM, Ghany MG, et al. Complication rate of percutaneous liver biopsies among persons with advanced chronic liver disease in the HALT-C trial. Clin Gastroenterol Hepatol. 2010;8(10):877-83. https:/ / doi.org/10.1016/j. cgh.2010.03.025. Medline:20362695

4. Tripodi A, Primignani M, Chantarangkul V, Clerici M, Dell \textquotesingleEra A, Fabris $\mathrm{F}$, et al. Thrombin generation in patients with cirrhosis: The role of platelets. Hepatology. 2006;44(2):440-5. https://doi.org/10.1002/ hep.21266. Medline:16871542

5. Lisman T, Bongers TN, Adelmeijer J, Janssen HLA, Maat MPM de, Groot PG de, et al. Elevated levels of von Willebrand Factor in cirrhosis support platelet adhesion despite reduced functional capacity. Hepatology. 2006;44(1):53-61. https://doi.org/10.1002/ hep.21231. Medline:16799972

6. Carnevale R, Raparelli V, Nocella C, Bartimoccia S, Novo M, Severino A, et al. Gut-derived endotoxin stimulates factor VIII secretion from endothelial cells. Implications for hypercoagulability in cirrhosis. Journal of Hepatology. 2017;67(5):950-956. https:// doi.org/10.1016/j.jhep.2017.07.002. Medline:28716745

7. Tripodi A, Primignani M, Chantarangkul V, Dell'Era A, Clerici M, Franchis R de, et al. An Imbalance of Pro-vs Anti-Coagulation Factors in Plasma From Patients With Cirrhosis. Gastroenterology. 2009;137(6):2105-11. https: / / doi.org/10.1053/j.gastro.2009. 08.045. Medline:19706293

8. Stravitz RT, Lisman T, Luketic VA, Sterling RK, Puri P, Fuchs M, et al. Minimal effects of acute liverinjury/acuteliverfailureonhemostasisas assessed by thromboelastography. J Hepatol. 2012;56(1):129-36. https:/ / doi.org/10.1016/j. jhep.2011.04.020. Medline:21703173

9. Lisman T, Bakhtiari K, Adelmeijer J, Meijers JCM, Porte RJ, Stravitz RT. Intact thrombin generation and decreased fibrinolytic capacity in patients with acute liver injury or acute liver failure. J Thromb Haemost. 2012;10(7):1312-9. https://doi.org/10.1111/ j.1538-7836.2012.04770.x. Medline:22568491

10. Drolz A, Horvatits T, Roedl K, Rutter K, Staufer K, Kneidinger N, et al. Coagulation parameters and major bleeding in critically 
V Dong, M Gosselin, N Jagarlamudi, et al

ill patients with cirrhosis. Hepatology. 2016;64(2):556-68. https://doi.org/10.1002/ hep.28628. Medline:27124745

11. Blasi A, Calvo A, Prado V, Reverter E, Reverter JC, Hernández-Tejero $M$, et al. Coagulation Failure in Patients With Acute-on-Chronic Liver Failure and Decompensated Cirrhosis: Beyond the International Normalized Ratio. Hepatology. 2018;68(6):2325-37. https:/ / doi. org/10.1002/hep.30103. Medline:29790188

12. Nadim MK, Durand F, Kellum JA, Levitsky J, O'Leary JG, Karvellas CJ, et al. Management of the critically ill patient with cirrhosis: A multidisciplinary perspective. J Hepatol. 2016;64(3):717-35. https:/ / doi.org/10.1016/j. jhep.2015.10.019. Medline:26519602

\section{SESSION 3-MUSCLE AND}

\section{NUTRITION IN CIRRHOSIS}

\section{CONFERENCE 8: IMPACT OF SARCOPENIA-A MONTANO-LOZA}

Sarcopenia is frequent in cirrhosis, with a prevalence reportedly ranging from $40 \%-70 \%$, related to method of diagnostic test $(1,2)$. The prevalence of sarcopenia is much higher than seen in other chronic conditions such as inflammatory bowel disease or chronic kidney disease (3). The annual incidence of sarcopenia also outweighs that seen with ascites or variceal bleeding (1), but similar to that of hepatic encephalopathy (HE), alluding to the close relationship between the two.

Patients with cirrhosis experience twice as much annual skeletal muscle loss when compared with population norms (4). This may in part be related to malabsorption or reduced oral intake, chronic inflammation, and hypogonadism (2). High ammonia levels may also promote muscle degradation (2).

Cross-sectional imaging is the current gold standard to quantify muscle mass; delineation of skeletal muscle with computerized tomography (CT) or magnetic resonance imaging (MRI) slices specifically at the L3 region has been found to have the best correlation with total body muscle mass and superior to analyzing just psoas muscle volume. Software can determine skeletal muscle volume and also distinguish subcutaneous and visceral adiposity. This is particularly advantageous in cirrhotic patients as other modes of quantifying muscle mass (such as with DEXA or body mass index) may be confounded by tissue edema or excess adiposity. Obtaining CT or MRI in every cirrhotic patient may however not be practical and hence other surrogates of sarcopenia are being evaluated, such as with point-of-care thigh ultrasound (5).

Specifically in cirrhosis, certain risk factors for sarcopenia have been identified and these include male sex, HE, C-reactive protein $>10 \mathrm{mg} / \mathrm{L}$, and $\mathrm{BMI}<25 \mathrm{~kg} / \mathrm{m}^{2}(6)$.

Sarcopenia has been found to influence mortality both in the pre-transplant (7) and post-transplant setting (8), and is associated with increased risk of developing HE (9) and sepsis (7). Several studies have confirmed these findings; in a study by Montano-Loza et al (7), sarcopenia was independently associated with increased pre-transplant mortality after adjusting for MELD, Child-Pugh and sodium. Similar results were seen in a subsequent international study by Carey et al (10) that included 396 North American patients, as well as in other smaller studies (11). Particularly in low MELD patients $(<15)$, presence of sarcopenia may add to the discriminant value for prediction of mortality than compared with MELD alone (12). Pre-transplant sarcopenia has also been associated with increased post-transplant increased length of hospital stay, increased intensive care unit stay (13), and bacterial infections (14). Post-transplant resolution of sarcopenia, though less well-studied, has also been found to influence overall survival positively (13).

Treatment options for sarcopenia focus on interrupting pathways that lead to muscle protein degradation, and boosting those that promote muscle synthesis and proliferation. Practically speaking however, the two key aspects that clinicians should implement in daily practice include optimizing of nutrition, as well as encouragement towards exercise. Adequate protein (1.2-1.5 g/ kg/day) and calories (35-40 kcal/ kg/day) should be consumed (15). Prolonged fasting for over 6 hours should be avoided, as this leads to accelerated breakdown of muscle (16). Hence patients should be advised to have a late-night high-protein snack prior to bedtime (16). Exercise should also be encouraged and may include a combination of aerobic and resistance training (17).

Finally, in cirrhotic men who are biochemically hypogonadal and sarcopenic, two clinical trials have 
demonstrated that testosterone therapy improved muscle mass, bone density and was well tolerated $(18,19)$. A recent study has also shown that loop diuretic use in cirrhotic patients may have a direct impact on impairing skeletal muscle differentiation and associated with higher risk of muscle loss (20).

\section{REFERENCES}

1. Dasarathy S, Merli M. Sarcopenia from mechanism to diagnosis and treatment in liver disease. J Hepatol. 2016;65(6):1232-44. https://doi.org/10.1016/j.jhep.2016.07.040. Medline:27515775

2. Sinclair M, Gow PJ, Grossmann M, Angus PW. Review article: sarcopenia in cirrhosis-aetiology, implications and potential therapeutic interventions. Aliment Pharmacol Ther. 2016;43(7):765-77. https://doi.org/ 10.1111/apt.13549. Medline:26847265

3. Pereira RA, Cordeiro AC, Avesani CM, Carrero JJ, Lindholm B, Amparo FC, et al. Sarcopenia in chronic kidney disease on conservative therapy: prevalence and association with mortality. Nephrol Dial Transplant. 2015;30(10):1718-25. https:/ / doi. org/10.1093/ndt/gfv133. Medline:25999376

4. Hanai T, Shiraki M, Ohnishi S, Miyazaki $\mathrm{T}$, Ideta $\mathrm{T}$, Kochi $\mathrm{T}$, et al. Rapid skeletal muscle wasting predicts worse survival in patients with liver cirrhosis. Hepatol Res. 2016;46(8):743-51. https://doi.org/10.1111/ hepr.12616. Medline:26579878

5. Tandon P, Low G, Mourtzakis M, Zenith L, Myers RP, Abraldes JG, et al. A Model to Identify Sarcopenia in Patients With Cirrhosis. Clin Gastroenterol Hepatol. 2016;14(10):147380.e3. https:/ / doi.org/10.1016/j.cgh.2016.04. 040. Medline:27189915

6. Guido Stirnimann, Maryam Ebadi, Isabela Bertoli De Simone, Vera C Mazurak, Tandon P, Montano-Loza AJ. Sarcopenia in Patients with Cirrhosis Is Associated with Male Gender, Child-Pugh Class $C$ and Inflammation. Hepatology. 2018;68(S1):1173A. https://doi. org/10.1002/hep.30257

7. Montano-Loza AJ, Meza-Junco J, Prado CMM, Lieffers JR, Baracos VE, Bain VG, et al. Muscle wasting is associated with mortality in patients with cirrhosis. Clin Gastroenterol Hepatol.
2012;10(2):166-73. https://doi.org/10.1016/j. cgh.2011.08.028. Medline:21893129

8. Kaido T, Ogawa K, Fujimoto Y, Ogura Y, Hata K, Ito $T$, et al. Impact of Sarcopenia on Survival in Patients Undergoing Living Donor Liver Transplantation. Am J Transpl. 2013;13(6):1549-56. https://doi.org/10.1111/ ajt.12221. Medline:23601159

9. Bhanji RA, Moctezuma-Velazquez C, DuarteRojo A, Ebadi M, Ghosh S, Rose C, et al. Myosteatosis and sarcopenia are associated with hepatic encephalopathy in patients with cirrhosis. Hepatol Int. 2018;12(4):377-86. https: / / doi.org/10.1007/s12072-018-9875-9. Medline:29881992

10. Carey EJ, Lai JC, Wang CW, Dasarathy S, Lobach I, Montano-Loza AJ, et al. A multicenter study to define sarcopenia in patients with end-stage liver disease. Liver Transpl. 2017;23(5):625-33. https://doi. org/10.1002/1t.24750. Medline:28240805

11. Vugt JLA van, Levolger S, Bruin RWF de, Rosmalen J van, Metselaar HJ, IJzermans JNM. Systematic Review and Meta-Analysis of the Impact of Computed TomographyAssessed Skeletal Muscle Mass on Outcome in Patients Awaiting or Undergoing Liver Transplantation. Am J Transpl. 2016;16(8):2277-92. https://doi.org/10.1111/ ajt.13732. Medline:26813115

12. Montano-Loza AJ, Duarte-Rojo A, MezaJunco J, Baracos VE, Sawyer MB, Pang JXQ, et al. Inclusion of Sarcopenia Within MELD (MELD-Sarcopenia) and the Prediction of Mortality in Patients With Cirrhosis. Clin Transl Gastroenterol. 2015;6(7):e102. https:/ /doi.org/10.1038/ctg.2015.31. Medline: 26181291

13. Montano-Loza AJ, Meza-Junco J, Baracos VE, Prado CMM, Ma M, Meeberg G, et al. Severe muscle depletion predicts postoperative length of stay but is not associated with survival after liver transplantation. Liver Transpl. 2014;20(6):640-8. https://doi.org/ 10.1002/lt.23863. Medline:24678005

14. Krell RW, Kaul DR, Martin AR, Englesbe MJ, Sonnenday CJ, Cai S, et al. Association between sarcopenia and the risk of serious infection among adults undergoing liver 
transplantation. Liver Transpl. 2013;19 (12):1396-402. https://doi.org/10.1002/lt. 23752. Medline:24151041

15. Merli M, Berzigotti A, Zelber-Sagi S, Dasarathy S, Montagnese S, Genton L, et al. EASL Clinical Practice Guidelines on nutrition in chronic liver disease. J Hepatol. 2019;70(1):172-93. https:/ / doi.org/10.1016/j. jhep.2018.06.024. Medline:30144956

16. Plank LD, Gane EJ, Peng S, Muthu C, Mathur $S$, Gillanders L, et al. Nocturnal nutritional supplementation improves total body protein status of patients with liver cirrhosis: A randomized 12-month trial Hepatology. 2008;48(2):557-566. https:/ / doi.org/10.1002/ hep.22367. Medline:18627001.

17. Duarte-Rojo A, Ruiz-Margáin A, MontañoLoza AJ, Macías-Rodríguez RU, Ferrando A, Kim WR. Exercise and physical activity for patients with end-stage liver disease: Improving functional status and sarcopenia while on the transplant waiting list. Liver Transpl. 2018;24(1):122-39. https://doi.org/ $10.1002 / 1 t .24958$

18. Yurci A, Yucesoy $M$, Unluhizarci $K$, Torun E, Gursoy S, Baskol M, et al. Effects of testosterone gel treatment in hypogonadal men with liver cirrhosis. Clin Res Hepatol Gastroenterol. 2011;35(12):845-854. https:// doi.org/10.1016/j.clinre.2011.09.005

19. Sinclair M, Grossmann M, Hoermann R, Angus PW, Gow PJ. Testosterone therapy increases muscle mass in men with cirrhosis and low testosterone: A randomised controlled trial. J Hepatol. 2016;65(5):906-913. https:/ / doi.org/10.1016/j.jhep.2016.06.007

20. Hanai T, Shiraki M, Miwa T, Watanabe S, Imai $\mathrm{K}$, Suetsugu A, et al. Effect of loop diuretics on skeletal muscle depletion in patients with liver cirrhosis. Hepatol Res. 2018;49(1):82-95. https://doi.org/10.1111/hepr.13244

\section{CONFERENCE 9: NUTRITION AND CIRRHOSIS-M MERLI}

The prevalence of malnutrition increases along with liver disease severity, and survival worsens with progressive malnourishment (1). Malnutrition, used as a synonym of under nutrition may however go unrecognized. It should also encompass the entity of sarcopenic obesity, given that the general prevalence of obesity and hence also the prevalence of cirrhosis and end-stage liver disease related to non-alcoholic fatty liver disease is increasing. Women have a physiologically lower muscle mass than men, which may make it more difficult to appreciate a decrease in muscle mass, and hence sarcopenia may be less sensitive in identifying malnutrition in women in the way it does with men. Women do, however, have more subcutaneous fat (2). There is a close relationship between episodes of decompensation, malnutrition, and sarcopenia, as well as hepatic encephalopathy, bacterial infections, and recurrent infections that lead to reduced survival in patients with cirrhosis.

All patients with cirrhosis should undergo a rapid nutritional screen with tools such as the Royal Free Hospital-Nutrition Prioritizing Tool or Liver Disease-Undernutrition Screening Tool. Those at highest risk of malnutrition are underweight (body mass index $<18.5 \mathrm{~kg} / \mathrm{m}^{2}$ ) or Child-Pugh C patients and should undergo a detailed nutritional assessment. A registered dietician should preferentially carry out the nutritional assessment taking into account muscle function and muscle mass, as well as dietary intake. Body mass index (BMI) has a limited utility as a surrogate of malnutrition as weight may stay the same or even increase, despite dramatic changes in body composition in patients with water retention. The correlation between different body composition assessment tools is weak, and data is varied as different muscles have been explored utilizing different cutoff values (3). Even with current standards of evaluating sarcopenia, there has been no correction of age with the cutoffs, despite the knowledge that muscle mass decreases with increasing age.

Survival rates improve when patients receive nutritional counselling from multi-disciplinary teams; when additional tools such as videos are used the impact is even increased. Physicians and patients alike should be aware of optimal meal calorie consumptions, with emphasis towards adequate protein intake. Ensuring adequate nutritional intake may help to reduce episodes of hepatic encephalopathy (4). Late evening calorie supplementation is recommended to avoid periods of starvation as this promotes breakdown of fat and muscle (5). Physical activity should also be encouraged in patients with cirrhosis to prevent sarcopenia (6). In obese patients, weight reduction 
could be considered, but protein intake should not be decreased. In patients with hepatic encephalopathy, protein restriction should not be prescribed and consumption of vegetal proteins and branched-chain amino acids may be useful.

There is evidence that in-hospital infections increase after liver transplantation (LT) in patients with advanced liver disease and malnutrition $(7,8)$. Sarcopenia pre-transplant may also be associated with post-LT mortality, intensive care stay and total hospital stay (7). Ideally, sarcopenia should be screened and targeted prior to LT. Early post-operative enteral nutrition should be considered. In patients with $\mathrm{HE}$, parenteral nutrition can be used if airway protection is a concern. Hyponatremia should also be carefully managed to avoid pontine myelinolysis. Sarcopenic obesity post-liver transplant should also be considered, and most patients who put on weight post-LT do so with adipose rather than muscle mass (9). Metabolic problems have been seen to arise as soon as within a year post-transplant (9), which may be attributed to steroid use and immunosuppression. In the setting of upper gastrointestinal bleeding, enteral nutrition should be withheld for 48-72 hours due to the increased risk of increased portal pressure and variceal re-bleeding. Nutritional support may accelerate resolution of hepatic encephalopathy and improve survival in patients with severe alcoholic hepatitis.

\section{REFERENCES}

1. Merli M, Riggio O, Dally L. Does malnutrition affect survival in cirrhosis? PINC (Policentrica Italiana Nutrizione Cirrosi). Hepatology. 1996;23(5):1041-6. https://doi.org/10.1002/ hep.510230516. Medline:8621131

2. Tandon P, Ney M, Irwin I, Ma MM, Gramlich L, Bain VG, et al. Severe muscle depletion in patients on the liver transplant wait list: its prevalence and independent prognostic value. Liver Transpl. 2012;18(10):1209-16. https:// doi.org/10.1002/lt.23495. Medline:22740290

3. Giusto M, Lattanzi B, Albanese C, Galtieri A, Farcomeni A, Giannelli V, et al. Sarcopenia in liver cirrhosis: the role of computed tomography scan for the assessment of muscle mass compared with dual-energy X-ray absorptiometry and anthropometry. Eur J Gastroenterol Hepatol. 2015;27(3):328-34. https://doi.org/10.1097/ MEG.0000000000000274. Medline:25569567
4. MaharshiS,SharmaBC,SachdevaS,Srivastava S, Sharma P. Efficacy of Nutritional Therapy for Patients With Cirrhosis and Minimal Hepatic Encephalopathy in a Randomized Trial. Clin Gastroenterol Hepatol. 2016;14(3):454-60.e3. https://doi.org/10.1016/j.cgh.2015.09.028. Medline:26453952

5. Plank LD, Gane EJ, Peng S, Muthu C, Mathur $S$, Gillanders L, et al. Nocturnal nutritional supplementation improves total body protein status of patients with liver cirrhosis: A randomized 12-month trial. Hepatology. 2008;48(2):557-66. https://doi.org/10.1002/ hep.22367. Medline:18627001

6. Dasarathy S, Merli M. Sarcopenia from mechanism to diagnosis and treatment in liver disease. J Hepatol. 2016;65(6):1232-44. https://doi.org/10.1016/j.jhep.2016.07.040. Medline:27515775

7. Montano-Loza AJ, Meza-Junco J, Baracos VE, Prado CMM, Ma M, Meeberg G, et al. Severe muscle depletion predicts postoperative length of stay but is not associated with survival after liver transplantation. Liver Transpl. 2014;20(6):640-8. https://doi. org/10.1002/lt.23863. Medline:24678005

8. Merli M, Giusto M, Gentili F, Novelli G, Ferretti G, Riggio O, et al. Nutritional status: its influence on the outcome of patients undergoing liver transplantation. Liver Int. 2010;30(2):208-14. https://doi.org/10.1111/ j.1478-3231.2009.02135.x. Medline:19840246

9. Choudhary NS, Saigal S, Saraf N, Mohanka R, Rastogi A, Goja S, et al. Sarcopenic obesity with metabolic syndrome: a newly recognized entity following living donor liver transplantation. Clin Transplant. 2015; 29(3):211-15. https://doi.org/10.1111/ ctr.12505. Medline:25594826

\section{CONFERENCE 10: HEPATIC ENCEPHALOPATHY AND DRIVING: A BUMPY ROAD-P WONG}

Liver disease is one of the top 10 causes of death for Canadians (1) and affects up to one in four Canadians (2). Approximately 3,000 deaths a year occur from chronic liver disease and only about 500 liver transplants are performed annually in 
Canada. Deaths arising from motor vehicle accidents (MVA) is also a top 10 cause of mortality, with roughly 2,500 deaths annually (3).

Overt hepatic encephalopathy (OHE) refers to patients with clinically evident hepatic encephalopathy (HE), usually those with West Haven HE grades II-IV. Roughly $30 \%-40 \%$ of cirrhosis patients will develop OHE in their lifetime (4). Development of OHE is a milestone event in a cirrhotic patient, and is a poor prognostic sign with several series showing that $>50 \%$ of patients will die within 1 year after their first episode of $\mathrm{OHE}(5,6)$. Covert hepatic encephalopathy (CHE) refers to those patients with either minimal HE or Grade I West Haven criteria HE. Estimations of the latter's prevalence are imprecise, with reported ranges of $20 \%-80 \%$ of patients being affected (4).

Several series using navigational simulators have shown that patients with minimal HE (MHE) have more frequent MVAs, road-edge excursions and centre crossings than patients without MHE $(7,8)$. Patients with cirrhosis who are involved in a MVA are more likely to need hospitalization after an accident and are at increased risk of mortality (9). Identification of patients with CHE is needed for patient and public safety.

Multiple tests exist for the detection of CHE. Paper and pencil tests have been the gold standard for years. The psychometric hepatic encephalopathy score (i.e., PHES) includes traditional tests such as the trail test, digit symbol test, serial dotting or line tracing tests and require training in order to administer the test properly (10). The test can be time consuming (45-60 minutes to administer) and is proprietary, requiring payment for its use. The MoCA (Montreal Cognitive Assessment) is desirable for its ease of administration and short duration, but lacks validation for hepatic encephalopathy (11). More sophisticated neurophysiologic tests such as EEG, or auditory evoked potentials are poorly accessible and are better utilized under the supervision of a neurologist.

The last decade has seen advances towards more user friendly, rapid automated tests. The inhibitory control test is an inexpensive, non-copyrighted exam requiring minimal time to administer (15 minutes) and does not require specialized training to use (12). The Stroop test is a smart phone application freely downloadable and simple to administer, provided the patient does not have red green colour blindness (13). The animal naming test was also shown to have high predictive value to distinguishing those affected with CHE (14). All of these tests have been validated for CHE.

However, no single test can definitively distinguish safe from unsafe drivers in CHE. As a general consensus, two tests should be administered to confirm the diagnosis.

Loss of autonomy is often significant for these patients and an empathetic approach when delivering this diagnosis and its implications is needed. Providing support, and enlisting the aid of family members in finding transportation solutions is crucial. Although difficult, this message must be firm and non-negotiable. The stance from the CMPA and CMA is clear, that for patient and public safety reasons, physicians have a legal obligation to report anyone that may be unsafe to drive (15). It is the Ministry of Transportation (MOT) that reserves the right to decide on further testing or revocation of one's licence. A brief written statement should be provided detailing why you do not feel they should until their decision is finalized.

Alberta, Quebec, and Nova Scotia have, "discretionary" as opposed to "mandatory" reporting, but precedent has been set by the Highway Traffic Act in Ontario, in that the protection of public safety supersedes all else, even one's patient physician relationship. Whether there exists a mandatory reporting condition (i.e., epilepsy) versus a temporary condition (i.e., cervical spondylosis), physicians have a duty and legal obligation to immediately report patients that are unsafe to drive. This principle has been upheld repeatedly in Canadian courts (16).

In conclusion, $\mathrm{CHE}$ is underdiagnosed and is clearly associated with increased risk of MVAs. Formalized testing for $\mathrm{CHE}$ is now automated, with high likelihoods of detection and ease of administration for office use. Failure to report drivers that continue to drive when they should not is unsafe and negatively erodes confidence in the medical profession. Physicians have a legal responsibility to report and fulfill their statutory duty towards public safety.

\section{REFERENCES}

1. Government of Canada SC. Leading causes of death, total population, by age group [Internet]. 2018 [cited 2019]. Available from: https://www150.statcan.gc.ca/t1/tbl1/en/ tv.action?pid=1310039401

2. Canadian Liver Foundation. Obesity linked to dramatic rise in liver disease [Internet]. [cited 2019]. Available from: http://liver.ca/ 
newsroom/press-releases /03-07-2016-Liver_ disease_may_affect_1_in_4.aspx

3. Government of Canada SC. Deaths and agespecific mortality rates, by selected grouped causes [Internet]. 2018 [cited 2019]. Available from: https://www150.statcan.gc.ca/t1/tbl1/ en/tv.action?pid=1310039201

4. Vilstrup H, Amodio P, Bajaj J, Cordoba $\mathrm{J}$, Ferenci P, Mullen KD, et al. Hepatic encephalopathy in chronic liver disease: 2014 Practice Guideline by the American Association for the Study Of Liver Diseases and the European Association for the Study of the Liver. Hepatology. 2014;60(2): 715-35.https:/ / doi.org/10.1002/hep.27210. Medline:25042402

5. Bustamante J, Rimola A, Ventura P-J, Navasa M, Cirera I, Reggiardo V, et al. Prognostic significance of hepatic encephalopathy in patients with cirrhosis. J Hepatol. 1999;30(5):890-5. https://doi.org/10.1016/ s0168-8278(99)80144-5

6. Jepsen P, Ott P, Andersen PK, Sørensen HT, Vilstrup H. Clinical course of alcoholic liver cirrhosis: a Danish population-based cohort study. Hepatology. 2010;51(5): 1675-82.https://doi.org/10.1002/hep.23500. Medline:20186844

7. Bajaj JS. Minimal hepatic encephalopathy matters in daily life. World journal of gastroenterology: WJG. 2008;14(23):3609-15. https://doi.org/10.3748/wjg.14.3609. Medline: 18595126

8. Bajaj JS, Wade JB, Gibson DP, Heuman DM, Thacker LR, Sterling RK, et al. The multidimensional burden of cirrhosis and hepatic encephalopathy on patients and caregivers. Am J Gastroenterol. 2011;106(9):1646-53. https:/ / doi.org/10.1038/ajg.2011.157. Medline:21556040

9. Bajaj JS, Ananthakrishnan AN, McGinley EL, Hoffmann RG, Brasel KJ. Deleterious effect of cirrhosis on outcomes after motor vehicle crashes using the nationwide inpatient sample. Am J Gastroenterol. 2008;103(7): 1674-81. https:/ /doi.org/10.1111/j.1572-0241. 2008.01814.x

10. Weissenborn K. PHES: One label, different goods. J Hepatol. 2008;49(3):308-12. https:/ / doi.org/10.1016/j.jhep.2008.06.023. Medline: 18644646

11. MOCA [Internet]. Available from: https:// www.parkinsons.va.gov/resources/MOCATest-English.pdf

12. Bajaj JS, Hafeezullah M, Franco J, Varma RR, Hoffmann RG, Knox JF, et al. Inhibitory control test for the diagnosis of minimal hepatic encephalopathy. Gastroenterology. 2008;135(5):1591-1600.e1.https:/ / doi.org/10. 1053/j.gastro.2008.07.021. Medline:18723018

13. Bajaj JS, Thacker LR, Heuman DM, Fuchs M, Sterling RK, Sanyal AJ, et al. The Stroop smartphone application is a short and valid method to screen for minimal hepatic encephalopathy. Hepatology. 2013;58(3): 1122-32. https:/ / doi.org/10.1002/hep.26309. Medline:23389962

14. Campagna F, Montagnese S, Ridola L, Senzolo M, Schiff S, Rui MD, et al. The animal naming test: An easy tool for the assessment of hepatic encephalopathy. Hepatology. 2017;66(1):198 208. https://doi.org/10.1002/hep.29146. Medline:28271528

15. Butcher DJM. CMA driver - Determining medical fitness to operate motor vehicles. CMAJ. 2007;177(1):65. https://doi.org/10.1503/cmaj. 1070065

16. Nguyen HH, Swain MG, Wong P, Congly SE. Canadian regulations and legal ramifications for hepatic encephalopathy: a descriptive analysis. CMAJ Open. 2018;6(4):E575-9. https: / / doi.org/10.9778/ cmajo.20180024. Medline:30510040

\section{CONFERENCE 11: CHALLENGES WITH LIVER TRANSPLANTATION: PALLIATIVE CARE-P TANDON, A BRISEBOIS}

As defined by the World Health Organization, palliative care is the active total care of patients whose disease is not responsive to curative treatment'. An approach to care using palliative principles improves the quality of life of patients and their families facing problems associated with lifethreatening illness, through the prevention and 
relief of suffering by means of early identification and impeccable assessment and treatment of pain and other problems, physical, psychosocial and spiritual' $(1,2)$. In addition to symptom management, advance care planning (ACP) is a central component of care using palliative principles. ACP is defined as a process that supports adults at any age or stage of health in understanding and sharing their personal values, life goals and preferences regarding future medical care (3). This integrated approach to care has already demonstrated significant benefits in other chronic disease populations (4-6). These include improved patients' symptoms, a higher likelihood of dying at home, more focused $\mathrm{ACP}$, better psychosocial health, reduced health care utilization and higher patient/family satisfaction. Data in cirrhosis is emerging. In a recent study of delisted liver transplant candidates (7), the integration of routine palliative care consultation was associated with a shorter duration to do not resuscitate (DNR) status, a decrease in intensive care unit (ICU) stay time and a positive family response to the incorporation of palliative care consults (7). Importantly, patient mortality was not hastened by this intervention. Palliative care has also been shown to improve health related quality of life (HRQoL) and decrease health care utilization in cirrhosis (8).

Rates of palliative care consultation remain low. Recent studies have reported palliative care consultation in $11 \%$ of patients ineligible for transplantation $(9,10)$, with $90 \%$ of referrals taking place within 72 hours of death (10).

There are several recognized barriers that contribute to this underutilization. Prognostication and prediction of the time course of death and disease trajectory is challenging in these patients (11). Patients with more compensated or well controlled cirrhosis may not appear as ill as they really are and severe decompensation can occur rapidly $(12,13)$. Few clinicians routinely screen for symptoms such as pain or muscle cramps in clinical practice, or feel comfortable managing these symptoms in the setting of cirrhosis. This leads to underestimation of symptom burden and under treatment (14). Recent reviews of cirrhosis do not include symptom management in their algorithms (15-17). Lastly, there is a common misconception about the role of palliative care as being limited to the last few days of life (18). It is vital to remember that palliative care is not simply about quelling the inevitable tide of death, but more importantly, hinges upon enriching the patient life that yet remains. Palliative principles are applicable to patients with years of life still left to live, but with serious illness and high symptom burden.

While it has been suggested that specific symptoms of decompensated liver disease, such as ascites or HE could be used as potential triggers for a palliative care consult (19), ideally, palliative care principles and end of life planning should be instituted in some capacity in all patients with cirrhosis and certainly prior to the onset of HE. This early integration of ACP can be applied by all health care practitioners and does not require consultation from trained palliative care health practitioners who may be needed in more severe cases or at the end of life.

The burden of cirrhosis is not only on patients. Informal caregivers are an essential component of the medical management of chronically ill patients and are vital to the financial viability of North American health care $(20,21)$. Although not studied directly in cirrhosis, patient outcomes improve with the involvement of informal caregivers (22). Their involvement leads to less complications and fewer hospital admissions (23-26). Informal caregivers are responsible for much of the care provided to patients with cirrhosis, taking a major role in medication management and the administration of palliative care (24). In their 2012 study, Rakoski et al found that one third of patients with cirrhosis identified an informal caregiver (24). These patients required twice the number of informal caregiving hours per week when compared with an age-matched population. Caregiver stress may be considered a trigger for palliative care consultation. Specialized palliative care services have been associated with both short- and long-term caregiver outcomes (27). Although not formally investigated in the setting of cirrhosis and HE, other strategies for easing caregiver burden are becoming more well-established and should be trialed in patients with cirrhosis. Potential interventions include multidisciplinary care with a social worker and a psychologist as well as focused family psychoeducation $(23,28)$. Targeted interventions to increase caregiver effectiveness, such as telephone interventions and caregiver support groups have been effective in other populations (29-31) and may also prove to be of benefit in HE. A short program of mindfulness and supportive group therapy proved beneficial for the management of caregiver burden in a recent study in patients with cirrhosis (32).

In summary, the routine use of palliative principles has the potential to optimize effective and 
comprehensive management of patients with cirrhosis and their caregivers. The number of studies evaluating this areas is growing steadily over time.

\section{REFERENCES}

1. WHO | WHO Definition of Palliative Care [Internet]. World Health Organization. [cited 2019]. Available from: https://www.who. int/cancer/palliative/definition/en/

2. Brisebois AJ, Tandon P. Working with palliative care services. Clin Liver Dis. 2015;6(2):37-40. https://doi.org/10.1002/ cld.493. Medline:31040984

3. Sudore RL. Redefining the "Planning" in Advance Care Planning: Preparing for Endof-Life Decision Making. Ann Intern Med. 2010;153(4):256. https:/ / doi.org/10.7326/00034819-153-4-201008170-00008. Medline:20713793

4. Cohen LM, Moss AH, Weisbord SD, Germain MJ. Renal Palliative Care. J Palliat Med. 2006;9(4):977-992. https://doi.org/10.1089/ jpm.2006.9.977. Medline:16910813

5. Schwarz ER, Baraghoush A, Morrissey RP, Shah AB, Shinde AM, Phan A, et al. Pilot Study of Palliative Care Consultation in Patients with Advanced Heart Failure Referred for Cardiac Transplantation. J Palliat Med. 2012;15(1):12-5. https://doi.org/10.1089/ jpm.2011.0256. Medline:22216757

6. Singer AE, Goebel JR, Kim YS, Dy SM, Ahluwalia SC, Clifford M, et al. Populations and Interventions for Palliative and End-ofLife Care: A Systematic Review. J Palliat Med. 2016;19(9):995-1008.https://doi.org/10.1089/ jpm.2015.0367. Medline:27533892

7. Lamba S, Murphy P, McVicker S, Smith JH, Mosenthal AC. Changing End-of-Life Care Practice for Liver Transplant Service Patients: Structured Palliative Care Intervention in the Surgical Intensive Care Unit. J Pain Symptom Manage. 2012;44(4):508-19. https://doi.org/ 10.1016/j.jpainsymman.2011.10.018. Medline: 22765967

8. Córdoba J, Flavià M, Jacas C, Sauleda S, Esteban JI, Vargas V, et al. Quality of life and cognitive function in hepatitis $\mathrm{C}$ at different stages of liver disease. J Hepatol. 2003;39(2):231-8. https://doi.org/10.1016/ s0168-8278(03)00189-2
9. Poonja Z, Brisebois A, van Zanten SV, Tandon P, Meeberg G, Karvellas CJ. Patients with cirrhosis and denied liver transplants rarely receive adequate palliative care or appropriate management. Clin Gastroenterol Hepatol. 2014;12(4):692-8. https://doi.org/10.1016/j. cgh.2013.08.027. Medline:23978345

10. Kathpalia P, Smith A, Lai JC. Underutilization of palliative care services in the liver transplant population. World J Transplant. 2016;6(3):594. https://doi.org/10.5500/wjt. v6.i3.594. Medline:27683638

11. Larson AM. Palliative Care for Patients with End-Stage Liver Disease. Curr Gastroenterol Rep [Internet]. 2015;17(5):440. Available from: https: / / doi.org/10.1007\%2Fs11894-0150440-6https: / / doi.org/10.1007/s11894-0150440-6. Medline:25855211

12. D'Amico G, Garcia-Tsao G, Pagliaro L. Natural history and prognostic indicators of survival in cirrhosis: A systematic review of 118 studies. J Hepatol. 2006;44(1):217-31. https://doi.org/10.1016/j.jhep.2005.10.013. Medline:16298014

13. Jalan R, Gines P, Olson JC, Mookerjee RP, Moreau R, Garcia-Tsao G, et al. Acute-on chronic liver failure. J Hepatol. 2012;57(6):1336-48. https://doi.org/10.1016/j.jhep.2012.06.026. Medline:22750750

14. Abrams GA, Concato J, Fallon MB. Muscle cramps in patients with cirrhosis. Am J Gastroenterol. 1996;91(7):1363-6.

15. Muir AJ. Understanding the Complexities of Cirrhosis. Clinical Therapeutics. 2015;37(8): 1822-36. https://doi.org/10.1016/j.clinthera. 2015.05.507. Medline:26188836

16. James J, Liou IW. Comprehensive Care of Patients with Chronic Liver Disease. Med Clin North Am. 2015;99(5):913-33. https:// doi.org/10.1016/j.mcna.2015.05.001. Medline:26320039

17. McPherson S, Lucey MR, Moriarty KJ. Decompensated alcohol related liver disease: acute management. BMJ. 2016;i124. https:// doi.org/10.1136/bmj.i124. Medline:26812946

18. Larson AM, Curtis JR. Integrating Palliative Care for Liver Transplant Candidates. JAMA. 2006;295(18):2168. https://doi.org/10.1001/ jama.295.18.2168. Medline:16684988 
19. Potosek J, Curry M, Buss M, Chittenden E. Integration of Palliative Care in End-Stage Liver Disease and Liver Transplantation. J Palliat Med. 2014;17(11):1271-7. https://doi. org/10.1089/jpm.2013.0167. Medline:25390468

20. Chari AV, Engberg J, Ray KN, Mehrotra A. The Opportunity Costs of Informal Elder-Care in the United States: New Estimates from the American Time Use Survey. Health Serv Res. 2014;50(3):871-82. https: / / doi.org/10.1111/1475-6773.12238. Medline:25294306

21. Hollander M, Liu G, Chappell N. Who Cares and How Much? The Imputed Economic Contribution to the Canadian Healthcare System of Middle-Aged and Older Unpaid CaregiversProvidingCaretoTheElderly.Health Q. 2009;12(2):42-9. https://doi.org/10.12927/ hcq.2009.20660. Medline:19369810

22. Smith CE, Piamjariyakul U, Yadrich DM, Ross VM, Gajewski B, Williams AR. Complex home care: part III--economic impact on family caregiver quality of life and patients' clinical outcomes. Nurs Econ. 2010;28(6):393-9, 414.

23. Adelman RD, Tmanova LL, Delgado D, Dion S, Lachs MS. Caregiver Burden. JAMA. 2014;311(10):1052. https://doi.org/10.1001/ jama.2014.304. Medline:24618967

24. Rakoski MO, McCammon RJ, Piette JD, Iwashyna TJ, Marrero JA, Lok AS, et al. Burden of cirrhosis on older Americans and their families: Analysis of the health and retirement study. Hepatology. 2011;55(1): 184-191. https:/ /doi.org/10.1002/hep.24616. Medline:21858847

25. Golics CJ, Basra M, Salek M, Finlay A. The impact of patients' chronic disease on family quality of life: an experience from 26 specialties. Int J Gen Med. 2013;6:787-98. https://doi. org/10.2147/ijgm.s45156. Medline:24092994

26. Jeffs L, Dhalla I, Cardoso R, Bell CM. The perspectives of patients, family members and healthcare professionals on readmissions: preventable or inevitable? J Interprof Care. 2014;28(6):507-12. https:/ / doi.org/10.3109/13561820.2014.923988. Medline:24913271

27. Abernethy AP,Currow DC, Fazekas BS, Luszcz MA, Wheeler JL, Kuchibhatla M. Specialized palliative care services are associated with improved short-and long-term caregiver outcomes. Supportive Care in Cancer. 2007;16(6):585-97. https://doi.org/10.1007/ s00520-007-0342-8. Medline:17960433

28. Madigan K, Egan P, Brennan D, Hill S, Maguire B, Horgan F, et al. A randomised controlled trial of carer-focussed multi-family group psychoeducation in bipolar disorder. Eur Psychiatry. 2012;27(4):281-4. https:// doi.org/10.1016/j.eurpsy.2010.12.008. Medline:21334858

29. Hepburn K, Lewis M, Tornatore J, Sherman CW, Bremer KL. The Savvy Caregiver program: the demonstrated effectiveness of a transportable dementia caregiver psychoeducation program. J Gerontol Nurs. 2007;33(3):30-6. Medline:17378189

30. Grant JS, Elliott TR, Weaver M, Bartolucci AA, Giger JN. Telephone Intervention With Family Caregivers of Stroke Survivors After Rehabilitation. Stroke. 2002;33(8):2060-2065. https: / /doi.org/10.1161/01.str.0000020711. 38824.e3. Medline:12154263

31. Chien L-Y, Chu H, Guo J-L, Liao Y-M, Chang $\mathrm{L}-\mathrm{I}$, Chen $\mathrm{C}-\mathrm{H}$, et al. Caregiver support groups in patients with dementia: a meta-analysis. Int J GeriatrPsychiatry. 2011;26(10):1089-98.https:/ / doi.org/10.1002/gps.2660. Medline:21308785

32. Bajaj JS, Ellwood M, Ainger T, Burroughs T, Fagan A, Gavis EA, et al. Mindfulness-Based StressReduction TherapyImprovesPatientand Caregiver-Reported Outcomes in Cirrhosis. Clin Transl Gastroenterol. 2017;8(7):e108. https: / / doi.org/10.1038/ctg.2017.38. Medline:28749453
SESSION 4-CRITICAL CARE AND LIVER TRANSPLANT IN THE ACLF PATIENT 
unit (CCU), a resource with limited availability and high resource utilization. Key CCU benefits include supporting organ failures and providing time for potential organ recovery. Within critical care, outreach is an important aspect that allows identifications of patients who may benefit from CCU admission early in the disease course. Early identification of patients is essential, both for patients with and without liver disease $(1,2)$. The later a patient is identified to be critically ill, the higher the chance of CCU admission and the higher the mortality rate is. Time to antibiotic administration is the key factor affecting mortality. During the first 48 hours, broad-spectrum antibiotics should be used and then narrowed after 48 hours. Patients with chronic liver disease also have higher mortality when admitted to the ICU compared with patients with other major chronic comorbidities such as stage 5 chronic kidney disease $(3,4)$. Validated pronostic indices include the CLIForgan failure score system and the SOFA score (5). Validated cutoffs for futility include SOFA score or 13 or more and blood lactate levels or 4 $\mathrm{mmol} / \mathrm{L}$ or more that are associated with a mortality over $90 \%$ (6). Mortality rises with increasing numbers of failing organs (7).

Sepsis is a major actor in acute-on-chronic liver failure (ACLF) patients during which patients have inadequate immune responses, with excessive systemic inflammation in some and dysfunction of immune mechanisms in others $(8,9)$. The frequent occurrence of invasive aspergillosis in patients with severe alcoholic hepatitis, associated with increased mortality is an example of this (10).

In ACLF, patients have a hyperdynamic state. Fluid balance is delicate in this population. Tools to guide volume management include mean arterial pressure, mixed venous blood saturation, central venous pressure, intra-abdominal pressure, and ultrasound monitoring of the inferior vena cava and heart cavities (11). Patients who are volume depleted will be overconstricted while those who are overloaded will develop organ congestion. Both situations lead to ischemia. The presence of a flow murmur may signify outflow tract obstruction and fluid overload. B-type natriuretic peptide (BNP) can help separate cirrhotic patients who are volume overloaded from those who are underfilled. Regarding fluid resuscitation, balanced salt solutions result in less hyperchloremia, greater normal bicarbonate levels, and less adverse renal events. Hypercholeremic acidosis carries a high rate of mortality in the general CCU population (12).

Cirrhotic patients with septic shock have a trend toward better survival with terlipressin compared with norepinephrine, but develop more adverse events including myocardial, visceral, and peripheral ischemia (13). Hydrocortisone does not affect mortality in ACLF patients. Profound shock and vasopressor requirement during CCU admission may lead to ischemic cholangiopathy even in patients without underlying liver disease (14). Albumin is commonly utilized in the CCU and has antioxidant and hemostatic effects. It is important in drug transport and has survival benefits in spontaneous bacterial peritonitis, but not in other bacterial infections in cirrhotic patients (15-17).

Aside from usual indications, renal replacement therapy is used in patients with liver failure to manage hyponatremia, hypercholeremia, acidosis, hyperammonemia and encephalopathy, and fluid overload (18). In terms of encephalopathy, intubation may be required. Once intubated, avoid excess sedation, utilize a feeding tube to provide nutritional support, and provide thromboprophylaxis. Extracorporeal membrane oxygenation (ECMO) needs further assessment in the setting of liver disease, mainly in acute liver failure.

\section{REFERENCES}

1. Seymour CW, Gesten F, Prescott HC, Friedrich ME, Iwashyna TJ, Phillips GS, et al. Time to Treatment and Mortality during Mandated Emergency Care for Sepsis. N Engl J Med. 2017;376(23):2235-44. https:/ / doi.org/10.1056/NEJMoa1703058. Medline:28528569

2. Arabi YM, Dara SI, Memish Z, Abdulkareem AA, Tamim HM, Al-Shirawi N, et al. Antimicrobial therapeutic determinants of outcomes from septic shock among patients with cirrhosis. Hepatology. 2012;56(6):2305-15. https://doi.org/10.1002/hep.25931. Medline: 22753144

3. O'Brien AJ, Welch CA, Singer M, Harrison DA. Prevalence and outcome of cirrhosis patients admitted to UK intensive care: a comparison against dialysis-dependent chronic renal failure patients. Intensive Care Med. 2012;38(6):991-1000. https:// doi.org/10.1007/s00134-012-2523-2. Medline:22456768 
4. Lone NI, Lee R, Walsh TS. Long-Term Mortality and Hospital Resource Use in ICU Patients With Alcohol-Related Liver Disease \ ast. Crit Care Med. 2019;47(1):23-32. https: / / doi.org/10.1097/ccm.0000000000003421. Medline:30247272

5. Jalan R, Saliba F, Pavesi M, Amoros A, Moreau R, Ginès $\mathrm{P}$, et al. Development and validation of a prognostic score to predict mortality in patients with acute-on-chronic liver failure. J Hepatol. 2014;61(5):1038-47. https://doi.org/10.1016/j.jhep.2014.06.012. Medline:24950482

6. McPhailMJW,KrieseS,HeneghanMA.Current management of acute liver failure. Curr Opin Gastroenterol. 2015;31(3):209-14. https:// doi.org/10.1097/MOG.0000000000000174. Medline:25850347

7. Theocharidou E, Pieri G, Mohammad AO, Cheung M, Cholongitas E, Agarwal B, et al. The Royal Free Hospital score: a calibrated prognostic model for patients with cirrhosis admitted to intensive care unit. Comparison with currentmodels and CLIF-SOFAscore.Am J Gastroenterol. 2014;109(4):554-62. https:/ /doi. org/10.1038/ajg.2013.466. Medline:24492755

8. Albillos A, Lario M, Álvarez-Mon M. Cirrhosisassociated immune dysfunction: Distinctive features and clinical relevance. J Hepatol. 2014;61(6):1385-96. https://doi.org/10.1016/j. jhep.2014.08.010. Medline:25135860

9. Wasmuth HE, Kunz D, Yagmur E, TimmerStranghöner A, Vidacek D, Siewert E, et al. Patients with acute on chronic liver failure display 'sepsis-like' immune paralysis. J Hepatol. 2005;42(2):195-201. https://doi. org/10.1016/j.jhep.2004.10.019. Medline: 15664244

10. Gustot T, Maillart E, Bocci M, Surin R, Trépo E, Degré $\mathrm{D}$, et al. Invasive aspergillosis in patients with severe alcoholic hepatitis. J Hepatol. 2014;60(2):267-74. https:/ / doi.org/10.1016/j. jhep.2013.09.011. Medline:24055548

11. Moller S, Henriksen JH. Cardiovascular complications of cirrhosis. Gut.2008;57(2):268 78. https:/ /doi.org/10.1136/gut.2006.112177

12. Semler MW, Self WH, Wanderer JP, Ehrenfeld JM, Wang L, Byrne DW, et al. Balanced Crystalloids versus Saline in Critically Ill Adults. N Engl J Med. 2018;378(9):829-39. https:/ / doi.org/10.1056/NEJMoa1711584. Medline:29485925

13. Choudhury A, Kedarisetty CK, Vashishtha C, Saini D, KumarS, Maiwall R, etal.Arandomized trial comparing terlipressin and noradrenaline in patients with cirrhosis and septic shock. Liver Int. 2016;37(4):552-61. https://doi. org/10.1111/liv.13252. Medline:27633962

14. Voigtländer $\mathrm{T}$, Jaeckel E, Lehner F, Manns MP, Lankisch TO. Liver transplantation for critically Ill patients with secondary sclerosing cholangitis: Outcome and complications. Liver Transpl. 2015;21(10):1295-9. https:/ / doi.org/10.1002/1t.24192. Medline:26069199

15. Garcia-Martinez R, Caraceni P, Bernardi M, Gines P, Arroyo V, Jalan R. Albumin: Pathophysiologic basis of its role in the treatment of cirrhosis and its complications. Hepatology. 2013;58(5):1836-46. https:// doi.org/10.1002/ hep.26338. Medline:23423799

16. Guevara M, Terra C, Nazar A, Solà E, Fernández J, Pavesi $M$, et al. Albumin for bacterial infections other than spontaneous bacterial peritonitis in cirrhosis. A randomized, controlled study. J Hepatol. 2012;57(4):759-65. https:/ / doi.org/10.1016/j. jhep.2012.06.013. Medline:22732511

17. Thévenot $T$, Bureau $C$, Oberti F, Anty $R$, Louvet A, Plessier A, et al. Effect of albumin in cirrhotic patients with infection other than spontaneous bacterial peritonitis. A randomized trial.J Hepatol. 2015;62(4):822-30. https://doi.org/10.1016/j.jhep.2014.11.017. Medline:25463545

18. Cardoso FS, Gottfried M, Tujios S, Olson $\mathrm{JC}$, and CJK. Continuous renal replacement therapy is associated with reduced serum ammonia levels and mortality in acute liver failure. Hepatology. 2017;67(2):711-20. https://doi.org/10.1002/hep.29488.Medline: 28859230

\section{CONFERENCE 13: ARTIFICIAL LIVER SUPPORT-SL NYBERG}

Artificial liver support devices have been studied for many years. Their use has shown improvements in hepatic encephalopathy but has not yet 
shown an improvement in survival. Devices for liver support are either artificial (hemofiltration, plasma exchange, or albumin-based) or cell-based (human cell lines or pig hepatocytes).

The Molecular Adsorbent Recycling System (MARS) uses albumin within the circuit to remove albumin-bound toxins along with charcoal and exchange resin columns. In 2015, MARS was used over 3,000 times worldwide. No survival benefit was seen with MARS in acute-on-chronic liver failure patients but improvements were seen in bilirubin, creatinine, and encephalopathy grade (1). The DIALIVE liver support system also uses albumin exchange to remove albumin-bound toxins, but contains an endotoxin removal system as well. It is currently being used in clinical testing. The Extracorporeal Liver Assist Device (ELAD) has been studied extensively and utilizes C3A hepatic cells in a plasma circuit. In a recent study looking at efficacy in acute alcoholic hepatitis patients, no overall survival benefit was seen when using ELAD compared with standard medical therapy. However, subgroup analysis showed that patients younger than age 50 with low creatinine and INR but high bilirubin had significantly higher survival in the ELAD treatment group compared with the non-ELAD treatment group (2). Follow-up study of alcoholic hepatitis patients who were younger than age 50 with low creatinine and INR treated with ELAD versus standard medical therapy did not show a survival benefit with this device.

The Mayo Bioartificial Liver Spheroid Reservoir (SRBAL) is similar to MARS but the charcoal and resin systems are replaced with a pig hepatocyte reservoir maintained in a spheroid configuration. SRBAL showed significantly improved survival in three large recent animal studies (3-5). Future liver cell therapies would involve a readily available supply of human hepatocytes. Genetically engineered animals can be used as incubators and this has been done in mice and pigs (6). Fumarylacetoacetate hydrolase (FAH)deficient pigs had FAH-positive hepatocytes transplanted into their livers. By 12 months, the liver is completely replaced with FAH-positive hepatocytes. Human hepatocytes can be transplanted into pig livers using the principle of fetal tolerization. Human hepatocytes are injected into fetal pigs prior to their development of an immune system (7). Currently, double knock-out pigs are used and hepatocytes are transplanted early in gestation. This has led to improvement in human cell engraftment and will hopefully lead to trials in humans.

\section{REFERENCES}

1. Bañares R, Nevens F, Larsen FS, Jalan R, Albillos A, Dollinger M, et al. Extracorporeal albumin dialysis with the molecular adsorbent recirculating system in acute-on-chronic liver failure: the RELIEF trial. Hepatology. 2013;57(3):1153-62. https:/ / doi.org/10.1002/ hep.26185. Medline:23213075

2. Thompson J, Jones N, Al-Khafaji A, Malik S, Reich D, Munoz S, et al. Extracorporeal cellular therapy (ELAD) in severe alcoholic hepatitis: A multinational, prospective, controlled, randomized trial. Liver Transpl. 2018;24(3):380-93. https://doi.org/10.1002/ lt.24986. Medline:29171941

3. Glorioso JM, Mao SA, Rodysill B, Mounajjed T, Kremers WK, Elgilani F, et al. Pivotal preclinical trial of the spheroid reservoir bioartificial liver. J Hepatol. 2015;63(2):388-98. https://doi.org/10.1016/j.jhep.2015.03.021. Medline:25817557

4. Li Y, Wu Q, Wang Y, Weng C, He Y, Gao M, et al. Novel spheroid reservoir bioartificial liver improves survival of nonhuman primates in a toxin-induced model of acute liver failure. Theranostics. 2018;8(20):5562-74. https:/ /doi.org/10.7150/thno.26540. Medline: 30555564

5. Chen HS, Joo DJ, Shaheen M, Li Y, Wang Y, Yang J, et al. Randomized Trial of Spheroid Reservoir Bioartificial Liver in Porcine Model of Posthepatectomy Liver Failure. Hepatology. 2019;69(1):329-42. https://doi.org/10.1002/hep.30184. Medline:30022502

6. Hickey RD, Mao SA, Glorioso J, Lillegard JB, Fisher JE, Amiot B, et al. Fumarylacetoacetate hydrolase deficient pigs are a novel large animal model of metabolic liver disease. Stem Cell Res. 2014;13(1):144-53. https:// doi.org/10.1016/j.scr.2014.05.003. Medline: 24879068

7. Fisher JE, Lillegard JB, McKenzie TJ, Rodysill BR, Wettstein PJ, Nyberg SL. In utero transplanted human hepatocytes allow postnatal engraftment of human hepatocytes in pigs. Liver Transpl. 2013;19(3):328-35. https:/ / doi.org/10.1002/lt.23598. Medline:23280879 
CONFERENCE 14: PERIOPERATIVE MANAGEMENT DURING LIVER TRANSPLANTATION FOR ACUTE-ON-
CHRONIC LIVER FAILUREFM CARRIER

Acute-on-chronic liver failure (ACLF) is an entity that requires the presence of organ dysfunction as defined by the CLIF (Chronic Liver Failure) Consortium organ dysfunction score in a patient with chronic liver disease (1). Grade 1 ACLF is defined by severe acute kidney injury (AKI), one organ dysfunction plus either mild AKI or grade 1 or 2 hepatic encephalopathy (HE), or mild AKI plus grade 3 or $4 \mathrm{HE}$. Grade 2 ACLF implies two organ dysfunctions and grade 3 ACLF implies three or more organ dysfunctions. The greater the ACLF grade, the higher the mortality is without liver transplantation (LT) with an observed 28-day mortality over $60 \%$ in grade 3 ACLF and a 7 -day mortality of $100 \%$ with five for more failing organs (2). Cohort studies showed that ACLF patients who undergo LT have 1-year survival rates from $60 \%$ to $84 \%$ (3-7). In one study from France, ACLF grade 3 patients who underwent LT had similar 1-year survival to those without ACLF (83.6\% versus $90 \%$, hazard ratio $=1.75$ [0.82-3.71]) and also had a major survival advantage over patients with ACLF who did not receive LT $(83.6 \%$ versus $7.9 \%, \mathrm{p}<0.0001)$.

Predictors of postoperative mortality in ACLF include age, elevated physiological scores (SOFA, CLIF-C ACLF score), higher ACLF grade, development of the acute respiratory distress syndrome (ARDS) and presence of persistently elevated lactate levels. ACLF patients who undergo LT generally have very high Model for End-Stage Liver Disease (MELD) scores and are on organ support such as vasopressors, mechanical ventilation and renal replacement therapy (RRT) compared with non-ACLF LT recipients $(3,4)$. Hemodynamically, they have a hyperdynamic state (high cardiac output, vasodilation, hypotension, splanchnic vasodilation and renal vasoconstriction) more pronounced than other end-stage liver disease (ESLD) patients, which makes their anaesthetic management delicate. Intraoperative fluid management in all ESLD patients undergoing LT is still controversial, but, a restrictive strategy seems to result in less bleeding and less pulmonary complications (8). Studies have suggested ESLD patients are vasopressin depleted similar to patients with septic shock and preferential use of a vasopressin-derived vasopressor might be associated with a lower portal pressure and a lower postoperative serum creatinine level. Overall, restrictive fluid management and use of vasopressin derivatives may be beneficial during LT.

ACLF patients undergoing LT have profound derangements in coagulation that include thrombocytopenia and coagulation factor deficits (9). However, regular coagulation tests are not a good reflection of global coagulation in patients with chronic liver disease and do not predict bleeding accurately (10). Factors affecting bleeding during LT include disease severity and volume management. Thromboelastography (TEG) can help predict bleeding $(11,12)$ and reduce the use of red blood cells and plasma during LT $(13,14)$. RRT use during LT may also improve outcomes in ACLF patients (15). All the aforementioned therapeutic approaches are based on low-quality evidence. Further evidence is required for most of them and criteria for ACLF patient selection for LT in this complex situation require further studies.

\section{REFERENCES}

1. Gustot T, Fernandez J, Garcia E, Morando F, Caraceni P, Alessandria C, et al. Clinical Course of acute-on-chronic liver failure syndrome and effects on prognosis. Hepatology. 2015;62(1):243-52. https://doi. org/10.1002/hep.27849. Medline:25877702

2. Moreau R, Jalan R, Gines P, Pavesi M, Angeli P, Cordoba J, et al. Acute-on-chronic liver failure is a distinct syndrome that develops in patients with acute decompensation of cirrhosis. Gastroenterology. 2013;144(7):1426-37, 1437. e1-9. https://doi.org/10.1053/j.gastro.2013. 02.042. Medline:23474284

3. ArtruF,LouvetA,RuizI,LevesqueE,Labreuche J, Ursic-Bedoya J, et al. Liver transplantation in the most severely ill cirrhotic patients: A multicenter study in acute-on-chronic liver failure grade 3. J Hepatol. 2017;67(4):708-15. https://doi.org/10.1016/j.jhep.2017.06.009. Medline:28645736

4. Karvellas CJ, Lescot T, Goldberg P, Sharpe $\mathrm{MD}$, Ronco JJ, Renner EL, et al. Liver transplantation in the critically ill: a multicenter Canadian retrospective cohort 
study. Critical Care. 2013;17(1):R28. https:// doi.org/10.1186/cc12508. Medline:23394270

5. Michard B, Artzner T, Lebas B, Besch C, Guillot $\mathrm{M}$, Faitot $\mathrm{F}$, et al. Liver transplantation in critically ill patients: Preoperative predictive factors of post-transplant mortality to avoid futility. Clin Transplant. 2017;31(12). https:/ / doi.org/10.1111/ctr.13115. Medline:28895204

6. Levesque E, Winter $A$, Noorah $Z$, Daurès JP, Landais $P$, Feray $C$, et al. Impact of acuteon-chronic liver failure on 90-day mortality following a first liver transplantation. Liver Int. 2017;37(5):684-693. https://doi. org/10.1111/liv.13355. Medline:28052486

7. Moon D-B, Lee S-G, Kang W-H, Song GW, Jung D-H, Park G-C, et al. Adult Living Donor Liver Transplantation for Acute-onChronic Liver Failure in High-Model for End-Stage Liver Disease Score Patients. Am J Transplant. 2017;17(7):1833-42. https:/ / doi. org/10.1111/ajt.14198. Medline:28097804

8. Mukhtar A, Salah M, Aboulfetouh F, Obayah G, Samy M, Hassanien A, et al. The use of terlipressin during living donor liver transplantation: Effects on systemic and splanchnic hemodynamics and renal function. Crit Care Med. 2011;39(6):1329-34. https:// doi.org/10.1097/CCM.0b013e3182120842. Medline:21336108

9. Tripodi A, Mannucci PM. The Coagulopathy of Chronic Liver Disease. N Engl J Med. 2011;365(2):147-56. https:/ / doi.org/10.1056/ nejmra1011170. Medline:21751907

10. Massicotte L, Carrier FM, Denault AY, Karakiewicz P, Hevesi Z, McCormack M, et al. Development of a Predictive Model for Blood Transfusions and Bleeding During Liver Transplantation: An Observational Cohort Study. J Cardio Vasc Anesth. 2018;32(4):1722-30. https://doi.org/10.1053/j.jvca.2017.10.011. Medline:29225154

11. Tafur LA, Taura P, Blasi A, Beltran J, Martinez-Palli G, Balust J, et al. Rotation thromboelastometry velocity curve predicts blood loss during liver transplantation. $\mathrm{Br}$ J Anaesth. 2016;117(6):741-8. https://doi. org/10.1093/bja/aew344. Medline:27956672

12. Sabate A, Blasi A, Costa M, Reyes R, Beltran J, Torres F. Assessment of rotational thromboelastometry for the prediction of red blood cell requirements in orthotopic liver transplantation. Minerva Anestesiol. 2018;84(4):447-54. https:/ / doi.org/10.23736/ S0375-9393.17.12023-7

13. Schumacher $C$, Eismann and $H$, Sieg L, Friedrich L, Scheinichen D, Vondran FWR, et al. Use of Rotational Thromboelastometry in Liver Transplantation Is Associated With Reduced Transfusion Requirements. Exp Clin Transpl. 2019;17(2):222-30. https:/ /doi. org/10.6002/ect.2017.0236. Medline:30295585

14. Smart L, Mumtaz K, Scharpf D, Gray NO, Traetow D, Black S, et al. Rotational Thromboelastometry or Conventional Coagulation Tests in Liver Transplantation: Comparing Blood Loss, Transfusions, and Cost. Ann Hepatol. 2017;16(6):916-23. https:/ / doi.org/10.5604/01.3001.0010.5283

15. Parmar A, Bigam D, Meeberg G, Cave D, Townsend DR, Gibney RTN, et al. An evaluation of intraoperative renal support during liver transplantation: a matched cohort study. Blood Purif. 2011;32(3): 238-48. https://doi.org/10.1159/000329485. Medline:21829016

\section{CONFERENCE 15: LIVER \\ TRANSPLANTATION IN ACUTE- ON-CHRONIC LIVER FAILURE: CHALLENGES WITH PREDICTING FUTILITY-CJ KARVELLAS}

Acute-on-chronic liver failure is a syndrome defined by acute decompensation of chronic liver disease with organ failures and high short-term mortality $(1,2)$. In the absence of liver transplantation (LT), acute-on-chronic failure (ACLF) grade discriminates between patients with different prognostic categories (2). As the ACLF grade increase, 28-day and 90-day mortality also increase. The Chronic Liver Failure Consortium (CLIF-C) ACLF Score incorporates age and white blood cell count along with CLIF-C organ failure score [bilirubin, creatinine, hepatic encephalopathy (HE), INR, blood pressure, and PF ratio] (3). Higher CLIF-C ACLF scores on admission to the 
intensive care unit (ICU) correspond to greater mortality. Patients who improve their ACLF grade at 72 hours post-admission have a natural history corresponding to the new ACLF grade at day 3 (4).

Within Canada, 3,000 to 4,000 patients die a year from liver disease and only about 500 LT procedures are performed a year. Allocation currently is based on the MELD sodium (MELD-Na) score resulting in the sickest patients receiving a transplant first. Factors that impact LT utility in ACLF patients include medical comorbidities, sarcopenia, severity of organ dysfunction, and donor factors. If patient survival is expected to be $50 \%$ or less at 5 years, it is of widespread acceptance that LT will be futile (5). Medical contraindications include body mass index greater than 40 , portopulmonary hypertension with mean pulmonary arterial pressure greater than $45 \mathrm{mmHg}$, left ventricular ejection fraction less than $50 \%$, and severe underlying lung disease. Sarcopenia has an impact on increasing length of hospital and ICU stay post LT, but not survival (6).

Severity of illness scores like Sequential Organ Failure Assessment (SOFA) and CLIF-C ACLF scores have more utility in discriminating between patients dying on the waitlist (differentiating waitlist mortality) than those with acceptable results post-LT. Advancing age or incremental increase in age are associated with 90-day mortality post-LT whereas SOFA is not (7). The more organ failures a patient has while in the ICU while awaiting an LT, the greater the chance of mortality within 30 days while on the waiting list (8). Other prognostic variables for ICU-mortality include increasing age and SOFA and lactate levels at 48 hours (7). The number of organ failures did not have as much of a significant effect on post-LT survival $(8,9)$. This may be due to careful selection of patients with ACLF in terms of LT suitability.

Aside from patient survival post-LT, other important end-points include length of ICU or hospital stay and post-LT complications, such as delirium. Even though ACLF grade did not significantly affect post-LT survival, it did impact length of ICU and hospital stay post-LT in the cohort by Artru et al (9). The Perioperative Survival Outcomes Following Liver Transplantation (P-SOFT) score incorporates both donor and recipient variables to predict survival postLT (10).
Patients denied LT rarely receive adequate palliative care or appropriated management such as do not resuscitate orders or palliative care referral (11).

\section{REFERENCES}

1. Bernal W, Jalan R, Quaglia A, Simpson K, Wendon J, Burroughs A. Acute-on-chronic liver failure. Lancet. 2015;386(10003):157687. https://doi.org/10.1016/S0140-6736(15) 00309-8

2. Moreau R, Jalan R, Gines P, Pavesi M, Angeli $\mathrm{P}$, Cordoba J, et al. Acute-on-chronic liver failure is a distinct syndrome that develops in patients with acute decompensation of cirrhosis. Gastroenterology. 2013;144(7):142637, 1437.e1-9. https://doi.org/10.1053/j. gastro.2013.02.042. Medline:23474284

3. Jalan R, Saliba F, Pavesi M, Amoros A, Moreau R, Ginès $\mathrm{P}$, et al. Development and validation of a prognostic score to predict mortality in patients with acute-on-chronic liver failure. J Hepatol. 2014;61(5):1038-47. https://doi.org/10.1016/j.jhep.2014.06.012. Medline:24950482

4. Karvellas CJ, Garcia-Lopez E, Fernandez J, Saliba F, Sy E, Jalan R, et al. Dynamic Prognostication in Critically Ill Cirrhotic Patients With Multiorgan Failure in ICUs in Europe and North America. Critical Care Medicine. 2018;46(11):1783-91. https:// doi.org/10.1097/ccm.0000000000003369. Medline:30106759

5. Biggins SW. Futility and rationing in liver retransplantation: When and how can we say no? J Hepatol. 2012;56(6):1404-11. https:/ / doi.org/10.1016/j.jhep.2011.11.027. Medline:22314427

6. Montano-Loza AJ, Meza-Junco J, Baracos VE, Prado CMM, Ma M, Meeberg G, et al. Severe muscle depletion predicts postoperative length of stay but is not associated with survival after liver transplantation. Liver Transpl. 2014;20(6):640-8. https://doi. org/10.1002/1t.23863. Medline:24678005

7. Karvellas CJ, Lescot T, Goldberg P, Sharpe $\mathrm{MD}$, Ronco JJ, Renner EL, et al. Liver transplantation in the critically ill: a multicenter Canadian retrospective cohort study. Critical Care. 2013;17(1):R28. https:/ / doi.org/10.1186/cc12508. Medline:23394270 
8. Thuluvath PJ, Thuluvath AJ, Hanish S, Savva Y. Liver transplantation in patients with multiple organ failures: Feasibility and outcomes. J Hepatol. 2018;69(5):1047-56. https: / / doi.org/10.1016/j.jhep.2018.07.007. Medline:30071241

9. ArtruF,LouvetA,RuizI,LevesqueE,Labreuche J, Ursic-Bedoya J, et al. Liver transplantation in the most severely ill cirrhotic patients: A multicenter study in acute-on-chronic liver failure grade 3. J Hepatol. 2017;67(4):708-15. https://doi.org/10.1016/j.jhep.2017.06.009. Medline:28645736

10. Rana A, Hardy MA, Halazun KJ, Woodland DC, Ratner LE, Samstein B, et al. Survival outcomes following liver transplantation (SOFT) score: a novel method to predict patient survival following liver transplantation. Am J Transplant. 2008;8(12):2537-46. https:// doi.org/10.1111/j.1600-6143.2008.02400.x. Medline:18945283

11. Poonja Z, Brisebois A, van Zanten SV, Tandon P, Meeberg G, Karvellas CJ. Patients with cirrhosis and denied liver transplants rarely receive adequate palliative care or appropriate management. Clin Gastroenterol Hepatol. 2014;12(4):692-8. https://doi.org/10.1016/j. cgh.2013.08.027. Medline:23978345

SESSION 5-CONTROVERSIES AND TREATMENTS

\section{CONFERENCE 16: CONTROVERSIES} IN LIVER TRANSPLANTATION:

\section{ALCOHOLIC HEPATITIS-MR LUCEY}

Whereas liver transplantation (LT) for end-stage liver disease due to alcohol has become standard of care, such that alcohol-related liver disease (ALD) has become the most frequent indication for liver transplantation in the US (1), LT for patients with life-threatening alcoholic hepatitis $(\mathrm{AH})$ not responding to medical treatment, sometimes referred to as early or rescue LT, remains hotly contested with strong opinions expressed both for and against $(2,3)$.
The nexus of alcohol-use disorder (AUD) and alcohol-associated liver disease (ALD)

In my opinion, the controversy surrounding rescue LT for severe AH stems from the complicated nexus of AUD and ALD. Our conflicted interpretation of AUD as either a disease or a disorder of choice has meant that there is a bedrock of opinion that considers patients with AUD to be personally responsible for their predicament and therefore less deserving of scarce resources such as a liver allograft (4). This contention, which appeared to have lost support has returned with the advent of LT for patients with severe AH. Recently, Solga et al have proposed explicitly that ALD patients should have less priority, stating that 'The Organ Procurement and Transplantation Network could review whether MELD for MELD allocation could be prioritized for patients with chronic liver disease ahead of those with $\mathrm{AH}^{\prime}$ (5). For a contrary view, I refer you to Benjamin et al's masterful deconstruction of these arguments (6).

A second source of confusion relates to outcome of AUD after LT. Irrespective of the stringency of selection, some ALD patients will return to drinking after LT (7). The transplant community remains conflicted as to whether this behaviour constitutes a failure of LT, or is simply the natural history of AUD.

Finally, there is concern that public support for donation to LT will decline if more ALD patients receive LTs. Evidence to support this contention is slim.

LT for ALD: a historical perspective (8)

In 1984, the NIH held a consensus conference regarding LT. This was a turning point that established that LT was a viable therapy rather than experimental. However, within the discussion, Dr. Steven Schenker asserted that ALD patients would be 'rarely suitable' for LT. This position had changed by 2003. In that year, the AASLD and the AST organized a conference entitled 'Minimal criteria for placement of adults on the LT waiting list'. At the conference, it was reported that the 6-months abstinence requirement ('the 6-month rule') was the norm in US transplant centres when assessing the suitability of patients with ALD. As a consequence, the interdiction on LT for $\mathrm{AH}$, which by its nature is preceded by drinking in the prior 6 weeks, persisted. However, even this limitation has now been breached. In 2017, EASL published its guideline on ALD, and stated that 'the selection of patients with AUD should not be based on the 
six-month criterion alone'. Additionally, 'early LT should be proposed to a minority of patients with severe AH not responding to medical therapy after a careful selection process'.

\section{Selection of ALD patients for LT}

It would be wrong to claim that there is a consensus in the US at present about rescue LT for $\mathrm{AH}$, and the six-month rule still has its adherents (9). Furthermore, it is endorsed by many payers and transplant centres. However unwavering adherence to the six-month rule leads to unwanted as well as wanted consequences. Its advocates point out that the six-month rule is associated with a modest reduction in risk of 'any use' of alcohol after transplant; and it is simple to apply. On the other hand, it is subject to manipulation and misinformation. It admits patients who will relapse after transplantation while excluding some patients who will not drink after transplantation. The alternative to a concrete abstinence rule is a psychosocial assessment that considers the risk of relapse as one of the elements contributing to the patient's ability to protect a liver allograft.

\section{Alcohol use by ALD patients after LT}

Even in cohorts selected by stringent criteria, return to alcohol use by some ALD recipients appears inevitable (7). It is important to distinguish between so-called slips, minor or transient use, often followed by renewed efforts toward abstinence from harmful sustained consumption, which is referred to as a relapse (7). Relapses are associated with all the injuries that occur to relapsing AUD patients in other circumstances: pneumonia, pancreatitis, delirium tremens, depression, marital breakdown, drunk driving, and work absences. Furthermore, harmful drinking leads to accelerated fibrosis of the allograft. Graft loss due to ALD is rare in the first 5 years, but occurs at 10 years in heavy drinkers.

\section{Rescue LT for AH}

To date the most influential (and iconoclastic) paper on LT for AH was the combined FrancoBelgian report of a pilot study of 26 patients who did not respond to medical treatment (10). All were approved following stringent psychosocial assessment. In the initial report, the survival of the pilot cohort was compared with 26 matched historical control patients, and an unequivocal benefit was observed. Dr Mathurin and colleagues are in the process of completing a prospective study with a greater number of subjects and contemporaneous controls. More recently, a consortium of 12 US transplant centres called ACCELERATE have published retrospective account of rescue LT for severe AH (11). The median interval from the last drink was 55 days, range 36-91. The mean MELD score at LT was 39. The patient and graft survival in the first 3 years post LT was excellent (94\% at 1 year) and similar to that observed in contemporaneous ALD patients with established abstinence.

In Mathurin's small cohort, relapse to alcohol was infrequent. In the US study, in the first 3 years, $16 \%$ of patients experienced relapse, while another $17 \%$ reported slips.

Given these data, one may ask rhetorically: why is rescue LT not standard of care for lifethreatening $\mathrm{AH}$ ? In answer, I would say that we are at a turning point. However, as outlined about, there continues to be confusion about the endpoints when considering outcome of LT in patients with AUD in general, and $\mathrm{AH}$ in particular. In the future, we need prospective studies that include clarity about selection, and management of AUD both in the lead up to and after LT. We also hampered by lack of definitive American data. Finally, we should not ignore the dynamics of transplantation, the need to engage all the stakeholders, while maintaining vigilance against promoting stigma.

\section{REFERENCES}

1. Cholankeril G, Ahmed A. Alcoholic Liver Disease Replaces Hepatitis C Virus Infection as the Leading Indication for Liver Transplantation in the United States. Clin Gastroenterol Hepatol. 2018;16(8):1356-8. https://doi.org/10.1016/j.cgh.2017.11.045. Medline:29199144

2. Lucey MR. Liver transplantation for severe alcoholic hepatitis-The PRO view. Liver Int. 2017;37(3):343-4.https://doi.org/10.1111/liv. 13343. Medline:28240837

3. Fung JYY. Liver transplantation for severe alcoholic hepatitis-The CON view. Liver Int. 2017;37(3):340-2. https://doi.org/10.1111/ liv.13286. Medline:28240836 
4. Moss AH. Should alcoholics compete equally for liver transplantation? JAMA. 1991;265(10):1295-8. https://doi.org/10. 1001/jama.265.10.1295. Medline:1995977

5. Solga SF, Serper M, Young RA, Forde KA. Transplantation for Alcoholic Hepatitis: Are We Achieving Justice and Utility? Hepatology. 2019;69(4):1798-802. https:/ / doi. org/10.1002/hep.30471. Medline:30561847

6. BenjaminM,TurcotteJG.Ethics, alcoholismand liver transplantation. In: Liver transplantation and alcoholic patient medical surgical and psychosocial issues | Surgery [Internet]. Cambridge: M. R. Lucey, T. P. Beresford, R. Merion, M. Benjamin, J. G. Turcotte; 1994 [cited 2019]. Available from: https://www. cambridge.org/ca/academic/subjects / medicine/surgery/liver-transplantationand-alcoholic-patient-medical-surgicaland-psychosocial-issues,

7. DiMartini A, Dew MA, Day $\mathrm{N}$, Fitzgerald MG, Jones BL, deVera ME, et al. Trajectories of alcohol consumption following liver transplantation. Am J Transplant. 2010;10(10):2305-12. https:// doi.org/10.1111/j.1600-6143.2010.03232.x. Medline:20726963

\section{CONFERENCE 17: ACUTE KIDNEY INJURY IN CIRRHOSIS-F WONG}

Acute kidney injury (AKI) is a commonly encountered complication in patients with decompensated cirrhosis. It is defined by an increase of $50 \%$ in serum creatinine from baseline that is presumed to have occurred within the past 7 days (Table 1). Hepatorenal syndrome (HRS) is a potentially reversible syndrome that occurs in patients with cirrhosis, ascites, and liver dysfunction, consisting of impaired renal function, marked abnormalities in cardiovascular function, and intense over-activity of the endogenous vasoactive systems. The most recent diagnostic criteria define it as stage 2 or 3 AKI in those patients with cirrhosis and ascites with no improvement in serum creatinine (decrease of creatinine to $\leq 0.3 \mathrm{mg} / \mathrm{dL}$ of baseline) after at least 48 hours of diuretic withdrawal and volume expansion with albumin. In addition, there should be no recent use of nephrotoxic agents and no significant proteinuria or hematuria, urine casts along with the absence of shock (1).

Several mechanisms lead to the evolution of renal dysfunction and injury in cirrhosis resulting in AKI.

Obstruction to portal flow secondary to cirrhosis, increased translocation of gut bacteria and bacterial products into the portal circulation and shear stress on portal vessels have vasodilatory effects on the splanchnic circulation. These mechanisms interact and amplify the circulatory dysfunction. Angiogenesis is also increased in the mesenteric circulation which results in an increased capacitance of the splanchnic circulation. This leads to an increase in the total capacitance of total circulating volume and leads to a reduction in effective arterial blood volume. This results in activation of various compensatory vasoconstrictor mechanisms in an attempt to reduce the circulatory capacitance. The kidneys are particularly sensitive to the vasoconstrictive effects of these systems which ultimately leads to reduced renal blood flow and glomerular filtration. Sodium retention is the compensatory mechanism of decreased glomerular filtration rate and decreased renal blood flow. It is the

Table 1: Diagnosis of renal dysfunction in cirrhosis

\begin{tabular}{|c|c|}
\hline Parameter & Definition \\
\hline Baseline SCr & $\begin{array}{l}\text { Stable } \mathrm{SCr} \leq 3 \text { months } \\
\text { If not available, a stable } \mathrm{SCr} \text { closest to the } \\
\text { current one } \\
\text { If no previous } \mathrm{SCr} \text { at all, use admission } \mathrm{SCr}\end{array}$ \\
\hline $\begin{array}{l}\text { Definition of } \\
\mathrm{AKI}\end{array}$ & $\begin{array}{l}\uparrow \text { in } \mathrm{SCr} \geq 26.5 \mu \mathrm{mol} / \mathrm{l}(0.3 \mathrm{mg} / \mathrm{dL}) \leq 48 \\
\text { hours, or } \\
\uparrow 50 \% \text { from baseline }\end{array}$ \\
\hline Staging & $\begin{array}{l}\text { Stage 1: } \uparrow \mathrm{SCr} \geq 26.4 \mu \mathrm{mol} / \mathrm{L}(0.3 \mathrm{mg} / \mathrm{dL}) \text { or } \\
\uparrow \mathrm{SCr} \geq 1.5-2.0 \times \text { from baseline } \\
\text { Stage } 2: \uparrow \mathrm{SCr}>2.0-3.0 \times \text { from baseline } \\
\text { Stage } 3: \uparrow \mathrm{SCr}>3.0 \times \text { from baseline, or } \mathrm{SCr} \\
\geq 352 \mu \mathrm{mol} / \mathrm{L}(4.0 \mathrm{mg} / \mathrm{dL}) \text { with an acute } \uparrow \\
\text { of } \geq 26.4 \mu \mathrm{mol} / \mathrm{L}(0.3 \mathrm{mg} / \mathrm{dL}) \text {, or Initiation } \\
\text { of renal replacement therapy }\end{array}$ \\
\hline
\end{tabular}


physiological response to increase the circulatory volume. The bacterial translocation includes bacteria, their DNAs and bacterial products, collectively known as pathogen-associated molecular patterns (PAMPs). These together with injured hepatocytes and their necrotic products known as damageassociated molecular patterns (DAMPs) also result in increased infectious and non-infectious activation of systemic inflammation and leads to production of inflammatory cytokines (2). In addition to the circulatory mechanisms, DAMPs and PAMPs, when filtered by the glomeruli, cause direct tubular damage in the kidneys and changes in renal microvasculature (3).

While a lot of research has been done in the field of biomarkers in renal dysfunction other than our current standard of using serum creatinine, these are not readily available to most practising clinicians. Those showing promise include NGAL and IL-18 $(4,5)$. An increasing number of positive biomarkers suggests a diagnosis of acute tubular necrosis (ATN) as the cause of AKI (6).

Once diagnostic criteria are fulfilled, the cause of renal failure must be determined and intrinsic causes excluded. HRS remains a diagnosis of exclusion. The current treatment algorithm emphasizes the importance of appropriate volume expansion with albumin $(1 \mathrm{~g} / \mathrm{kg}$, maximum $100 \mathrm{~g} /$ day for 2 days) prior to diagnosis of HRS. On top of its quantitative decrease, albumin has qualitative defects in chronic liver disease. Albumin therapy has several mechanisms of action that include antioxidant effects and immunomodulation (7). Once HRS is diagnosed, vasoconstrictor treatment is the next step with renal replacement therapy being reserved for non-responders that are suitable transplant candidates (8). Terlipressin is the most studied drug in the treatment of HRS and responders have increased survival $(9,10)$ and has similar efficacy than norepinephrine that requires intensive care unit monitoring (11). Liver transplantation is the definitive treatment for AKI not responding to therapy. The optimal timing and the indication for combined liver-kidney transplantation remains difficult to define. Early referral is key (12).

\section{REFERENCES}

1. Angeli P, Gines P, Wong F, Bernardi M, Boyer TD, Gerbes A, et al. Diagnosis and management of acute kidney injury in patients with cirrhosis: revised consensus recommendations of the International Club of Ascites. Gut. 2015;64(4):531-7. https://doi.org/10.1136/ gutjnl-2014-308874. Medline:25631669

2. Albillos A, Lario M, Álvarez-Mon M. Cirrhosisassociated immune dysfunction: Distinctive features and clinical relevance. J Hepatol. 2014;61(6):1385-96. https://doi.org/10.1016/ j.jhep.2014.08.010. Medline:25135860

3. Gomez H, Ince C, DeBacker D, Pickkers P, Payen D, Hotchkiss J, et al. A unified theory of sepsisinduced acute kidney injury: inflammation, microcirculatory dysfunction, bioenergetics, and the tubular cell adaptation to injury. Shock. 2014;41(1):3-11. https:/ / doi.org/10.1097/SHK. 0000000000000052. Medline:24346647

4. Piano S, Brocca A, Angeli P. Renal Function in Cirrhosis: A Critical Review of Available Tools. Semin Liver Dis. 2018;38(03):230-41. https:/ / doi.org/10.1055/s-0038-1661372. Medline:30041275

5. Belcher JM, Sanyal AJ, Peixoto AJ, Perazella MA, Lim J, Thiessen-Philbrook H, et al. Kidney biomarkers and differential diagnosis of patients with cirrhosis and acute kidney injury. Hepatology. 2014;60(2):622-32. https://doi. org/10.1002/hep.26980. Medline:24375576

6. Puthumana J, Ariza X, Belcher JM, Graupera I, Ginès P, Parikh CR. Urine Interleukin 18 and Lipocalin 2 Are Biomarkers of Acute Tubular Necrosis in Patients With Cirrhosis: A Systematic Review and Meta-analysis. Clin Gastroenterol Hepatol. 2017;15(7):1003-13.e3. https:/ / doi.org/10.1016/j.cgh.2016.11.035. Medline:28013112

7. Garcia-Martinez R, Caraceni P, Bernardi M, Gines P, Arroyo V, Jalan R. Albumin: Pathophysiologic basis of its role in the treatment of cirrhosis and its complications. Hepatology. 2013;58(5):1836-46. https://doi. org/10.1002/hep.26338. Medline:23423799

8. Wong F, Angeli P. New diagnostic criteria and management of acute kidney injury. J Hepatol. 2017;66(4):860-1. https://doi.org/10.1016/j. jhep.2016.10.024. Medline:27984175

9. Piano S, Schmidt $\mathrm{HH}$, Ariza $X$, Amoros A, Romano A, Hüsing-Kabar A, et al. Association Between Grade of Acute on Chronic Liver Failure and Response to Terlipressin and Albumin in Patients With 
Hepatorenal Syndrome. Clin Gastroenterol Hepatol. 2018;16(11):1792-1800.e3. https:// doi.org/10.1016/j.cgh.2018.01.035. Medline:29391267

10. Sanyal AJ, Boyer TD, Frederick RT, Wong F, Rossaro L, Araya V, et al. Reversal of hepatorenal syndrome type 1 with terlipressin plus albumin vs. placebo plus albumin in a pooled analysis of the OT-0401 and REVERSE randomised clinical studies. Aliment Pharmacol Ther. 2017;45(11): 1390-402.https://doi.org/10.1111/apt.14052. Medline:28370090

11. Mattos ÂZ de, Mattos AA de, Ribeiro RA. Terlipressin versus noradrenaline in the treatment of hepatorenal syndrome: systematic review with meta-analysis and full economic evaluation. Eur J Gastroenterol Hepatol. 2016;28(3):345-51. https://doi. org / 10.1097 / MEG.0000000000000537. Medline:26649801

12. Wong F, Leung W, Beshir MA, Marquez M, Renner EL. Outcomes of patients with cirrhosis and hepatorenal syndrome type 1 treated with liver transplantation. Liver Transpl. 2015;21(3):300-307. https://doi. org/10.1002/lt.24049. Medline:25422261

\section{CONFERENCE 18: TREATMENT OF HCV IN PATIENTS WITH DECOMPENSATED CIRRHOSIS-JJ FELD}

Hepatitis C viral infection (HCV) has become a much easier disease to treat for the majority of those affected with the advent of direct-acting antivirals (DAAs). However, it does remain a challenge in those with decompensated cirrhosis. Delaying treatment after liver transplantation (LT) is safer and results in higher sustained virologic response (SVR) rates, but makes LT necessary, exposes patients to drug-drug interactions (DDIs) and to the risk of fibrosing cholestatic hepatitis. The current goals of care for this patient group are to i) maximize treatment response, ii) avoid harm, and iii) to decide when to and when not to treat.

In the SOLAR-1 trial in patients with ChildPugh-(CP) B and C cirrhosis and infection with genotype 1 and 4 , the combination of sofosbuvir, velpatasvir and ribavirin led to SVR rates around
$90 \%$ when given for 12 or 24 weeks (1). In the SOLAR-2 trial with the same patient population and study drugs, the results were comparable in Child-Pugh B patients (SVR 87-96\%), but were inferior in Child-Pugh C patients (SVR 78-85\%) (2). $\mathrm{HCV}$ becomes increasingly difficult to treat once a patient has an episode of DAA failure. Selecting the best therapy for maximizing sustained virologic response (SVR) hence becomes crucial. After SVR, most patients had improvements of one to five points in their MELD score, but a certain minority showed deterioration. Rates of serious adverse events were higher in Child-Pugh $\mathrm{C}$ patients with around one third. It is hard to differentiate drug toxicity from the natural history of advanced cirrhosis. Current evidence supports the use of ribavirin (weight-based dosing) in improving SVR rates in certain patient populations, particularly those with genotype 3 and advanced cirrhosis as evidenced by the ASTRAL-4 trial (3). Moderate anemia is a common side-effect of ribavirin treatment.

Drug combinations with protease inhibitors (PIs) such as paritaprevir, ritonavir, ombitasvir and dasabuvir is safe and very effective in patients with Child-Pugh A cirrhosis and genotype 1 infection with SVR rates of $89-100 \%$ (4). However, cases of hepatic decompensation and death in Child-Pugh B and C patients have led to an absolute contra-indication of PIs in these patients. Direct drug toxicity has also been reported in PIsfree regimens (5), but overall the experience with these drugs is very reassuring.

Real world data have shown that DAA regimens are very safe in Child-Pugh A patients, but that decompensation occurs in about half of others (6). Predictors of decompensation were serum albumin $<35 \mathrm{~g} / \mathrm{L}$, MELD score over 14 and genotype 3 patients. The same albumin threshold of 35 and age over 65 were identified in another cohort (7). In the data from the English expanded access program, the mid-term survival without adverse events in Child-Pugh $C$ patients was very low, which questions the use of DAA in these patients (8).

There still is some doubt as to how much DAA regimens can make it possible to avoid liver transplantation in patients with decompensated cirrhosis. The concept of the MELD purgatory has been brought up to reflect the situation of patients with moderate biochemical improvements, but ongoing clinical problems without access to transplantation. In a European cohort, 
delisting was possible mostly in patients with a baseline MELD score below 16 (49\%), but rare in patients with baseline MELD 16-20 (18\%) and over 20 (15\%) (9). The BE3A score has been proposed to identify patients using the following criteria: body mass index $<25$, absence of encephalopathy, absence of ascites, albumin $>35 \mathrm{~g} / \mathrm{L}$ and ALT $>60 \mathrm{IU} / \mathrm{L}$. Those with a score of 4 or 5 were the most likely to turn out to be Child-Pugh A after 36 weeks of follow-up. This score performs probably best at identifying those who will not benefit for treatment before transplantation.

\section{REFERENCES}

1. Charlton M, Everson GT, Flamm SL, Kumar P, Landis C, Brown RS, et al. Ledipasvir and Sofosbuvir Plus Ribavirin for Treatment of HCVInfectioninPatientsWithAdvanced Liver Disease. Gastroenterology. 2015;149(3):64959. https://doi.org/10.1053/j.gastro.2015.05. 010. Medline:25985734

2. Manns M, Samuel D, Gane EJ, Mutimer D, McCaughan G, Buti M, et al. Ledipasvir and sofosbuvir plus ribavirin in patients with genotype 1 or 4 hepatitis $C$ virus infection and advanced liver disease: a multicentre, open-label, randomised, phase 2 trial. Lancet Infect Dis. 2016;16(6):685-97. https://doi. org/10.1016/S1473-3099(16)00052-9

3. Curry MP, O'Leary JG, Bzowej N, Muir AJ, Korenblat KM, Fenkel JM, et al. Sofosbuvir and Velpatasvir for $\mathrm{HCV}$ in Patients with Decompensated Cirrhosis. N Engl J Med. 2015;373(27):2618-28. https:// doi.org/10.1056/NEJMoa1512614. Medline: 26569658

4. Poordad F, Hezode C, Trinh R, Kowdley KV, Zeuzem S, Agarwal K, et al. ABT-450/ r-ombitasvir and dasabuvir with ribavirin for hepatitis C with cirrhosis. N Engl J Med. 2014;370(21):1973-82.https:/ /doi.org/10.1056/ NEJMoa1402869. Medline:24725237

5. Dyson JK, Hutchinson J, Harrison L, Rotimi $\mathrm{O}$, Tiniakos D, Foster GR, et al. Liver toxicity associated with sofosbuvir, an NS5A inhibitor and ribavirin use. J Hepatol. 2016;64(1):234-38. https://doi.org/10.1016/j.jhep.2015.07.041. Medline:26325535

6. Maan R, van Tilborg M, Deterding K, Ramji A, van der Meer AJ, Wong F, et al. Safety and Effectiveness of Direct-Acting Antiviral Agents for Treatment of Patients With Chronic Hepatitis C Virus Infection and Cirrhosis. Clin Gastroenterol Hepatol. 2016;14(12):1821-1830. e6. https:/ /doi.org/10.1016/j.cgh.2016.07.001. Medline:27404965

7. Foster GR, Irving WL, Cheung MCM, Walker AJ, Hudson BE, Verma S, et al. Impact of direct acting antiviral therapy in patients with chronic hepatitis $C$ and decompensated cirrhosis. J Hepatol. 2016;64(6):1224-31. https: / / doi.org/10.1016/j.jhep.2016.01.029. Medline:26829205

8. Cheung MCM, Walker AJ, Hudson BE, Verma S, McLauchlan J, Mutimer DJ, et al. Outcomes after successful direct-acting antiviral therapy for patients with chronic hepatitis $\mathrm{C}$ and decompensated cirrhosis. J Hepatol. 2016;65(4):741-47. https://doi.org/10.1016/j. jhep.2016.06.019. Medline:27388925

9. BelliLS,BerenguerM,CortesiPA,Strazzabosco M, Rockenschaub S-R, Martini S, et al. Delisting of liver transplant candidates with chronic hepatitis $C$ after viral eradication: $A$ European study. J Hepatol. 2016;65(3):524-31. https://doi.org/10.1016/j.jhep.2016.05.010. Medline:27212241 